\title{
The Verbal Complex in Continental West Germanic
}

\author{
Hans den Besten \& Jerold A. Edmondson
}

bron

Hans den Besten \& Jerold A. Edmondson, 'The Verbal Complex in Continental West Germanic.' In: Werner Abraham (ed.), On the Formal Syntax of the Westgermania. Papers from the '3rd Groningen Grammar Talks'. Groningen, January 1981. John Benjamins Publishing Company, Amsterdam/Philadelphia 1983, p. 155-216.

Zie voor verantwoording: https://www.dbnl.org/tekst/best005verb01 01/colofon.php

Let op: boeken en tijdschriftjaargangen die korter dan 140 jaar geleden verschenen zijn, kunnen auteursrechtelijk beschermd zijn. Welke vormen van gebruik zijn toegestaan voor dit werk of delen ervan, lees je in de gebruiksvoorwaarden.

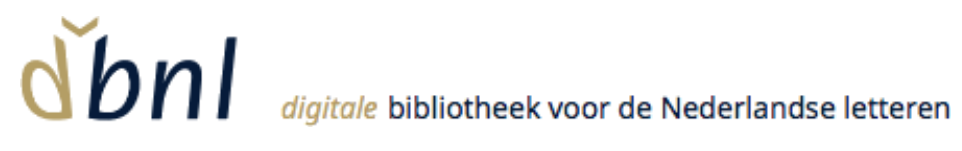




\title{
The verbal complex in continental West Germanic
}

\author{
Hans den Besten \\ Rijksuniversiteit Amsterdam \\ and
}

Jerold A. Edmondson

University of Texas at Arlington

There are ten parts of speech, and they are all troublesome. An average sentence, in a German newspaper, is a sublime and impressive curiosity; it occupies a quarter of a column; it contains all the ten parts of speech not in regular order, but mixed; it is built mainly of compound words constructed by the writer on the spot, and not to be found in any dictionary - six or seven words compacted into one, without joint or seam - that is, without hyphens, it treats of fourteen or fifteen different subjects, each enclosed in a parenthesis of its own, with here and there extra parentheses which reenclose three or four of the minor parentheses, making pens within pens: finally, all the parentheses, one of which is placed in the first line of the majestic sentence and the other in the middle of the last line of it - after which comes the VERB, and you find out for the first time what the man has been talking about; and after the verb - merely by way of ornament, as far as I can make out, - the writer shovels in 'haben sind gewesen gehabt haben 
geworden sein,' or words to that effect, and the monument is finished.

Mark Twain.

The Awful German language.

\section{Introduction}

The position of the verb in the Continental West-Germanic languages is Janus-faced. As many investigators have remarked, matrix clauses evidence some characteristics of SVO word order, whereas introduced embedded clauses (S) reveal the SOV word order pattern. Such divided typological loyalties have thus rightly been the topic of much discussion. Cf. Bach (1962, 1968), Bierwisch (1963), Lehmann (1971, 1972), Vennemann $(1974,1975)$, Koster (1975) and Hawkins (1979) to name only a few. The discussion in these works has centered around the issues: which of the two orders OV/VO constitutes the majority and which the minority pattern of these languages and in which direction and by what mechanisms are these languages changing. Contrary to the often heard claim, the OV/VO distribution doesn't always or even often correspond to the opposition dependent/main clause, since in the vast majority of sentence patterns the main verb follows the verbal complements in sentences involving periphrastic verbal constructions, i.e. all those with auxiliaries. For this reason and a lot of others we don't need to discuss here, we will assume an underlying SOV major pattern for this language group. The apparent SVO order in main clauses, we further assume, results from a general rule placing the tense-bearing element in second syntactic position in declaratives and in wh-questions. A similar rule puts the tense bearing element in first position for some other types of main clauses. Thus, following usual practice we will direct our attention primarily at embedded clauses in as much as we presume these clauses to reveal the underlying word order more directly than main clauses.

However enlightening the dependent clause order might be, the word order dilemma can not be satisfactorily resolved by restricting one's attention to the relative position of the verb and verbal complements in this subtype. A consistent SOV language, according to Greenberg's Universal 16, should require that an inflected auxiliary always follow the main verb. Steele's (1975) subsequent study of generically diverse languages uncovers a wider distribution for such auxiliaries, showing that they surface in sentence initial, sentence 
second or sentence final position. If we assign the numbers 1 through 4 to the

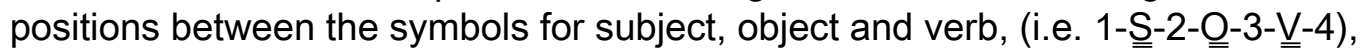
the two observations can be combined into one implicational universal.

I. (SOV) $\rightarrow \sim$ (Aux position 3$)$

(The auxiliary in an SOV language does not occur between object and verb). An SOV language prohibits placing the inflected auxiliary before the sentence final main verb. Furthermore, should a language evolve mixed typologies, for example SOV and SVO patterns, then an inflected auxiliary in position 3 might reflect this hybridization. As Hawkins (1979:620) has demonstrated, languages develop in harmony with synchronic universals, 'at each stage in their historical evolution, languages remain consistent with synchronic universal implications.'

In the following we investigate a number of diverse forms of the West Germanic languages, showing the family of rules that position inflected auxiliaries exactly in position three. Assuming that the West-Germanic languages have predominently SOV typology, the Law of Contraposition $(P \rightarrow Q) \leftrightarrow(\sim Q \rightarrow \sim P)$ will force us to conclude that these languages also manifest nascient SVO patterns, which is of course in agreement with the observation of many investigators. What will be novel in our account of the syntactic change in progress in this family is how the language specific rules conform to simple and well-established linguistic processes, the most important of which will be rule generalization.

\section{The Double Infinitive Construction}

Our investigations of the West-Germanic languages turned up two candidates that remain effectively SOV throughout the verb complex. West Frisian (spoken in the province of Friesland, the Netherlands) and Low German (still found among some in N. Germany) put the inflected auxiliary behind the main verb:

(1)

West Frisian (data from Erik Reuland)

a. dat er it boek lêze kent hat

that he the book read can(PP) has

'that he has been able to read the book.'

b. dat er de bal net goaien hoecht hat

that he the ball not throw need(PP)has

'that he has not needed to throw the ball.'

Low German (data taken from Lange (1981:63-4)) 
c. dat he dat book lesen kunnt hett

'that he has been able to read the book.'

d. *dat he dat book hett lesen künn'n.

As one would expect for an SOV language, the infinitives lêze/lesen are always followed by their determining modal verb kent/kunnt in the participal form and kent/kunnt, in turn, are followed by their determining perfect auxiliary hat/hett, the tensed finite element of a complex verb phrase. In main clauses, as in High German or Dutch, the finite verb appears in second syntactic position. Nevertheless, we see the well-established pattern that the determining element consistently dictates the paradigmatic form of the verbal element on its immediate left.

We have selected an illustration like 1, however, with a particular intent in mind. Unlike Frisian and Low German, the more widely spoken West-Germanic languages, High German and Dutch, do not behave as expected of SOV-languages in precisely this sentence type. Whenever a modal verb governing a main verb is itself put into the perfect tense, as in 1, a structure ensues that is traditionally known as the DOUBLE INFINITIVE CONSTRUCTION (DIC). This sentence type of the Dutch and High German varieties of West-Germanic and missing from Frisian, Low German, English and North-Germanic, cf. Lange (1981:64), will evidence a systemic pattern of variation allowing us insight into change across these languages.

Consider, now, the German equivalents of 1 :

(2)

\section{German}

a. ... dass er das Buch hat lesen können

that he the book has read can(inf.)

b. ... dass er den Ball nicht hat (zu) werfen brauchen

that he the ball not has to throw need(inf.)

In lieu of the expected participle form gekonnt only the infinitival form können may appear in 2a; lesen, as predicted, takes the infinitival form. Hence, the sentence appears to end in two infinitives, thus the shibboleth double infinitive construction. In more complex cases three, four or even more infinitives can occupy this position. This perplexing feature strikes nearly everyone who has learned German, and is probably the source of anecdotes about German professors ending an hour lecture with a five-minute heap of verbs.

But, beyond the paradigmatically anomalous FORM of the verb können, sentence 2 also shows a completely unexpected ORDER of elements. The finite auxiliary hat precedes both infinitives, i.e. demonstrates VO-behavior, whereas lesen and können serialize according to the OV-pattern. 
Finally, consider the corresponding case in Dutch, where we find the following equivalents of 1 .

(3)

Dutch

a. dat hij het boek heeft kunnen lezen

that he the book has can(inf.) read

b. dat hij de bal niet heeft hoeven gooien

that he the ball not has need(inf.) throw

Even though the verbal complex as a whole appears sentence final, the order of elements in this structure, taken pairwise, demonstrates the VO-pattern. As in the case of German, the modal verb kunnen governs the infinitive form, this time on its right.

The problem of form and position, of the inter- and intralanguage variation with respect to the DIC has been a troublesome feature in grammatical analyses for both traditional and modern treatments. However, we intend to show that this complex set of facts is capturable in term of a systematic, relatively transparent and theoretically interesting description. We, in particular, will show:

(A) that the above mentioned languages and a number of their non-standard variants can be described in terms of basically the same deep structure order of elements.

(B) that the rules deriving the unexpected syntactic phenomena concerning the DIC and word order can be described in terms of basically the same transformational rules.

(C) that the individual differences will largely be describable in terms of rule generalization, running from Frisian/Low German (no rule) over High German (restricted application) to Dutch (completely generalized application).

(D) that some of the other differences will be describable in terms of the manner each language variant chooses to analyze constants with respect to the rules in question.

In the history of descriptive grammar nearly every grammarian has been struck by the anomalous phenomena we are calling the DIC. Indeed, the number of names attached to this construction testifies to the amount of interest paid to it. It has been called: (a) Doppelte Infinitivkonstruktion (DIC); (b) Ersatzinfinitiv, (c) Infinitivisches Partizip, (d) infinitivus pro participio and doubtless others. Nearly everyone since at least Jakob Grimm (1969/1898:195) has called attention to it. Thus, Grimm says: 
Wenn nun nhd. nicht das allein stehende, sondern das mit einem inf. verbundene part. scheinbar selbst in den inf. verwandelt wird, so begreift sich so seltsame structur bloss aus der zufälligen ähnlichkeit starker participialformen mit dem inf., der wirkliche inf. wäre widersinnig.

When in Modern German the participial - if combined with an infinitive apparently itself turns into an infinitive, then such bizarre structure can only be understood as the accidental similarity of strong participle forms with the infinitive. The true infinitive would be counterintuitive. (our translation.)

Grimm is here referring to one account of the historical source of the DIC, according to which the infinitive and participle merged for certain members of the seventh class of the strong verbs. ${ }^{1}$

The German prescriptive grammarian and lexicographer Daniel Sanders invokes homophony in accounting for the unexpected word order. In many respects his treatment (Sanders 1898) represents a synchronic recapitulation of Grimm and Lachmann's account of the presumed historical sources of this construction. Sanders is also most valuable for his abundant store of documented sentences, many of which we have employed as illustrations here.

Bech (1955) like Sanders has collected a wealth of interesting examples, which he analyzes as configurational templates or patterns of the language. Since both of these investigations antedate generative descriptive techniques, only taxonomies are provided. Furthermore, neither addresses the question of language variation.

Bierwisch (1963:114) formulates probably the first attempt to deal with the DIC in generativist terms. He advocates changing the verb feature [+inf, +part] into [+inf, -part] just in case an infinitive precedes. There are further conditions on the rule that block the change if the complementizer $z u$ is present and make the rule sensitive to the position of haben. A second rule called HABEN-UMSTELLUNG positions a finite form of haben (the perfect auxiliary) to the left of the infinitives under certain conditions. Reis (1974:314) and Kohrt (1979:3-5) point out the manifest inadequacy of this treatment, noticing that the movement rule for German can invert (a) non-finite forms of haben and (b) also the future auxiliary werden. Examples of these are given in 4 below.

(4)

a. Er wird ihn haben schlagen wollen.

He will him have hit want

b. Ich glaube, dass sie ihn wird treffen wollen.

I believe that she him will meet want 
Recent treatments of the DIC in German have emphasized the variation among speakers. As we intend to show at length, this portion of German syntax evidences multiple forms that correlate with different styles and geographic areas. To a lesser extent there is variation in Dutch.

Interlanguage variation, as illustrated in 1 to 3 , as well as intralanguage diversity have experienced an inconstant fate in 20th century linguistics, because such data have been dealt with in a schizophrenic manner. Many investigators have insisted that one can and should describe only one homogeneous speech communities. This perspective in its most extreme form could, following Popper (1962:31), be branded essentialism, and would correspond to the Platonic view of some in the exact sciences. Ergo: nature is shaped in invariant essences that are reflected in the real world only imperfectly. Variance is consequently the product of imperfect observation, an artefact and not a significant property of reality.

What strikes the biologist and dialectologist, on the other hand, is the in-exhaustable individuality in nature; every flower, every insect, every idiolect is unique. Such an enormous potential for diversity within a single species dictates collection and classification and all but prevents transcending a taxonomy. It was only with the development of the theory of molecular genetics that such opposing viewpoints for investigating the physical and the natural worlds could be harmoniously resolved. Once variation was seen not as troublesome interference to observation but as a direct outgrowth of the nearly astronomical number of gene combinations, then a generalization capturing and predicting explanation became possible.

Even the layman notes the heterogeneity in natural language. The assumption of an ideal speaker/hearer living in a monolithic speech community is counterfactual, but the description of language in terms of transpersonal constructs is indispensible. Unfortunately, the idealization, homogeneous speech community, has not always been used like the ideal gas or the ideal spring in physics to enable one to formulate laws. Instead, it has often taken on the status of an immunization strategy; thus making some claims irrefutable. While less true today, many still remember the 'your dialect-my dialect' gambit from only a few years ago. Variation has also been denied systematic significance by calling it performance. Lötscher (1978) while writing for the dialectologist in one place opts for this approach in dealing with the diversity in the DIC. He notes that the continuously increasing obligatoriness of a movement rule as a function of the complexity of a construction is 'ein typisches Charakteristikum einer performanzbedingten Regel, die dazu 
dient, schwierige Konstruktionen zu einfacheren aufzulösen.' (a typical characteristic of a performance conditioned rule that serves to resolve difficult constructions into simpler ones.) While appeals to performance play a very minor role in Lötscher's informative article, we must point out that rules that produce a continuous, non-discrete output need not be performance rules. In invoking performance as a factor one is espousing essentialism to the extent that this claim rests on the assumption that continuously varying language behavior is probabilistic and therefore not systematic. Our data suggest for the DIC something quite different; that there is an underlying system connecting various lects.

Another avenue of retreat suggested to account for the lack of homogeneity in the DIC has been proposed by Kohrt (1979) and Reis (1979) in separate papers. The former sees the need of differentiating a 'Kernbereich' (central area) and 'dialektale Randzonen' (dialectal border areas). Despite this severing into two systems Kohrt pessimistically predicts that there remain 'immer noch ein gut Teil dialektaler und ideolektaler Variation, der nur sehr schwer zu erfassen ist.' (still a good deal of idiolectal and dialectal variation that is very difficult to capture.) Reis advocates a similar division into a core grammar and a patch-up grammar, saying: 2

Wer die vorgetragenen Analysen akzeptiert, hat sich meines Erachtens auf folgendes eingelassen: Er betrachtet die Grammatik einer Sprache als ein unvollständiges System im folgenden Sinn: Die grammatischen Regeln $x, y, z$ sind nicht anhand aller und für alle linguistischen, 'grammatischen' Situationen definiert,... (16)

(Whoever has accepted the analyses presented, has, in my judgment, opened the way for the following, he is viewing the grammar of a language as an incomplete system in the following sense. The grammatical rules $x, y$ and $z$ are not defined for all linguistic, 'grammatical' situations.)

The view of grammar suggested by both these keen observers crucially involves a discontinuity. This discontinuity in the object of description can fall along two dimensions; either the rules for describing the Hochsprache cannot be elaborated to cover the periphery (Kohrt) or the rules producing the central core of sentences are incapable of producing sharp wellformedness decisions for less commonly employed, or in some sense less central, outputs (Reis). While we have not carried out extensive sociolinguistic case studies of the language variants discussed here and have relied in large part on attested examples found in written language or on unsystematic observation, our data strongly suggest not discontinuity but that speakers control continuous and 
uninterrupted subintervals of the total spectrum of wellformed sentences in a language continuum, though the size of this subset may vary from speaker to speaker. During actual production speakers can constantly switch code levels across the lects that their grammar subtends, as Labov has observed. ${ }^{3}$

In the beginning of modern linguistic description of German, linguists were interested in developing rule systems that captured the transdialectal standard language. More recent work on the DIC has concentrated on variation in the verbal complex. Indeed, in the auxiliary complex -as in English- the diversity of syntactic alternatives is particularly apparent. Not so, however, with Dutch, which unlike German does not manifest a wide range of heterogeneity. Most studies have indicated only two minimumly varying sub-systems of the standard language, i.e. the northern variant, in use in The Netherlands and the southern variant, in use in Belgium, even if the division doesn't exactly parallel national borders. None of the literature on Dutch that we are familiar with is primarily concerned with variation in the DIC. Moreover, our own investigation indicates some diversity, but diversity of a quite different sort than that found in the German lects. Oversimplifying, Dutch generally shows the DIC FORM 'across the board' without any significant variation; only the POSITION of elements lacks total homogeneity. Cf. below. The Dutch verbal complex follows, with some minor exceptions to be mentioned, the VO-pattern, as example 3 above illustrated. It is to this deviation from the general OV-properties of Dutch that much interest has been drawn.

Until 1975 traditional grammars of Dutch merely noted the FORM and POSITION of elements in the DIC without offering a theoretically interesting account of it. Evers $(1973,1975)$ altered this attitude of benign neglect by successfully bringing the significance of this syntactic fact to the attention of a wider circle of linguists. He related it to the previous discussions of PREDICATE RAISING (which he renamed as VERB RAISING) in generative grammar and showed its importance for questions of cyclic rule application. Evers' work managed to concentrate the interest of many Dutch grammarians in the generativist tradition on this construction and its theoretical applications. Unfortunately, not all of this discussion is readily available in print; some of the more important and accessible contributions include: Nieuwenhuijsen (1975), Zwarts (1975), Van Riemsdijk (1978), Hoekstra/Moortgat (1979), De Haan (1979) and Den Besten (1981). ${ }^{4}$ Part of this discussion attempts to redefine Evers' rule of VERB RAISING, which derives the Dutch surface VO order in the verbal complex from an underlying OV order. 
In particular the question was posed as to whether it was possible to formulate VERB RAISING as a LOCAL rule in the sense of Emonds (1976). Nearly all investigators agree that it can. However, unanimity about the necessary type of transformation does not extend to the nature of the complements involved. The choice of complement types has corresponding consequences for the issue of cyclicity.

Returning for a moment for a brief survey of more traditional scholarship on Dutch, we have found that if variation is discussed at all, then three differences in the word order of the verbal complex are noted: (a) the position of past participles; (b) the behavior of verbs with SEPARABLE PREFIXES; and (c) the nature of verb complement type as a function of the VO-pattern. A. Pauwels (1953) presents data on regional differences in the use of word order in connection with auxiliaries and main verbs in verbal complexes with two members. Pauwels (1970) contrasts synchronic and diachronic data in the use of participles and separable prefixes in northern vs. southern forms of speech. Vanacker (1970) documents the order of elements with respect to the position of the main verb within the verbal complex for a few southern dialects. Stroop (1970) presents a dialectological survey of the order of verbal elements in spoken Dutch in the Netherlands. Koelmans (1965) shows the historical development for data of the type discussed by Vanacker. These studies constitute the major investigations of the verbal complex in the post-war era.

In summarizing the Dutch scholarship, we have the impression that the relative lack of variation in Dutch has determined a different research program than for German and its dialects, where richer diversity from one for of speech to another has led more to taxonomic classification than to theory-oriented research. Evers (1975) treated the two languages in tandem and chose to ignore their differences.

\section{Infinitivization and Inversion in German}

Having pointed out the sentence type under study here, discussed its variation and the difficulty of capturing non-discrete data in a monolithic grammar, we now move on to making a proposal for German that will yield the correct distribution of attested forms in different linguistically and speaker-determined environments. We will have little to say here about the grammar of Frisian/Low German, since these West-Germanic languages show only marginal signs of the DIC. The German rules below without INFINITIVIZATION and INVERSION would suffice for Frisian and Low German with only slight revamping. ${ }^{5}$ 
We begin by proposing a set of base rules for the relevant part of German as a background against which the necessary additions for the DIC can be thrown into relief. Once the principle of organization for the German verbal complex becomes clear, we will refine the first proposal in terms of a more adequate model. Cf. Edmondson (1980:62). ${ }^{6}$

(5)
a. $\mathrm{S} \rightarrow \mathrm{NP} \mathrm{VP}_{\mathrm{t}}$
b. $\mathrm{VP}_{\mathrm{t}} \rightarrow$ VP $\left\{\begin{array}{l}\mathrm{TM} \\ \mathrm{zu}-+\mathrm{INF}\end{array}\right\}$
c. VP $\rightarrow$ VP Modal
d. VP $\rightarrow$ VP。 Pass
e. $\mathrm{VP}_{\circ} \rightarrow \quad \cdots(\mathrm{NP}) \quad \mathrm{V}$
f. Modal $\rightarrow$ INF $\left\{\begin{array}{l}\text { könn- } \\ \text { mög- } \\ \text { müss- } \\ \text { woll- } \\ \text { soll- } \\ \text { dürf- }\end{array}\right\}$
g. TM $\rightarrow\left\{\begin{array}{c}\text { pres } \\ \text { past } \\ \text { fut }\end{array}\right\}$
h. fut $\rightarrow$ (INFwerd-) pres
i. Pass $\rightarrow$ PART werd-
j. Perf $\rightarrow$ PART $\left\{\begin{array}{l}\text { hab- } \\ \text { sei- }\end{array}\right\}$

The essential characteristic of 5 reflects Behaghel's oberstes Gesetz 'highest law' of word order ' ...das geistig eng Zusammengehörige (wird) auch eng zusammengestellt...' (1932:4) (that which in the mind belongs close together is placed close together). The classical transformational manner to express government among elements of the verbal complex, vintage 1957, is to generate two sister nodes in deep structure, one of which then affixes to a neighbor element. Here INF and könn-, mög-, müss-, etc. as well as PART and hab-/sei- are created as sisters. The transformation AUX-AFFIXATION can then attach a tense marker, zu+INF, INF or PART to the syntactic element on its immediate left. 
(6)

\section{AUX-AFFIXATION}

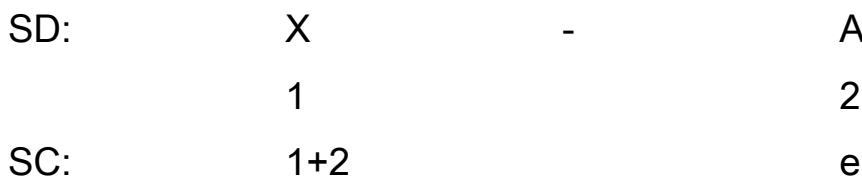

Condition: $A \in\{I N F$, PART, pres, past, $z u-+I N F\}$

In the course of a derivation the affixes are adjoined as sisters onto the next left element by repeated application of a transformation. Thus, unlike English AFFIX-HOPPING, not the order but only the structure of the verbal complex is altered. Cf.

(7)

a. wiss- PART+hab INF+müss pres $\rightarrow$ wiss+PART hab+INF müss+pres

known have must

b. wiss- INF+müss- INF+werd- pres $\rightarrow$ wiss+ INF müss+INF werd+pres

known must will

c. erzähl- PART+hab PART+hab pres $\rightarrow$ erzähl+PART hab+PART hab+press

told have has

d. wiss- INF+müss- PART+hab- pres $\rightarrow$ wiss+INF müss+PART hab+pres

know must have

Where there no DIC, then derivations like $7 \mathrm{~d}$ would yield the unacceptable surface form

(8)

\section{${ }^{*}$ wissen gemusst hat}

know must have

It is forms like $7 \mathrm{~d}$ that fall into the scope of rules leading to the DIC.

Some of the features of the rule system 5 deserve comment before proceeding. In particular, we wish to emphasize the points of difference between English and some of the other members of the West Germanic family. Rule $5 \mathrm{c}$ recursively expands a VP into a VP plus Modal or Perf. Unlike most varieties of English, the German and Dutch lects we have studied regularly allow more than one modal, e.g. German turnen können muss 'must be able to do gymnastics.' Furthermore, the southern forms of German regularly show Präteritum-Schwund 'missing preterite'; instead of preterite inflection this missing form of the verb paradigm is normally replaced with the perfect. And, in order to construct the Plusquamperfekt 'past perfect', there is reduplica- 
tion of the perfect. Thus, in place of gegangen war 'had gone', one hears the double perfect gegangen gewesen ist 'have have gone'. These cases motivate the recursively embedded VP. Nonetheless, this feature results in strong overgeneration. For example, 5 produces strings like:

(9)

a. * weil er gegangen gewesen gewesen ist.

because he gone been been has

b. *weil er gegangen sein können gemusst hat

because he gone been can must has

c. *weil er turnen können kann

because he do gymnastics can can

d. * weil er turnen können können kann

because he do gymnastics can can can

to name just a few deviant examples. Cases such as those in 9 are not possible in any kind of German familiar to us. In general one cannot double the same modal. Nevertheless, some kinds of repetition may be marginally possible if they aren't given the same interpretation, i.e. epistemic vs. modal. It is unclear to us exactly how to state these restrictions and whether 9 represents illformed syntactic strings or merely semantically uninterpretable ones.

Secondly, the rule for dealing with the future auxiliary werden, $5 \mathrm{~h}$, automatically insures that werden (somewhat like the English modals) appears only in paradigmatic forms corresponding to the traditional present tense, assuming that würde, the subjunctive, counts as present. Attempts to force another finite or an infinite form on the future auxiliary always produce unacceptable results. ${ }^{7}$

(10)

a. * wissen werden muss (before a modal, i.e. werden)

know will must [+INF]

b. *wissen geworden hat/list (before a perfect, i.e. werden)

know willed has [+PART]

c. * wissen wurde (in past tense, i.e. werden)

know willed [+PAST]

d. *um morgen rechtzeitig ankommen

in order tomorrow punctually arrive

zu werden (i.e. werden)

to will $[+\mathrm{INF}]$

Thirdly, the subcategorization in $5 a, 5 d$ and $5 e$ (cf. $V P_{t}$ and $V_{P_{0}}$ ) captures the positional restrictions of various paradigmatic forms. While German (and Dutch) positions modals more liberally than English, the tenses, of course, 
must be placed on the highest VP and the passive auxiliary must occur adjacent to the main verb. As in Akmajian/Steele/Wasow (1979) and in Gazdar Pullum, Sag (1980) these subcategorization restrictions are stated at various VP levels.

Finally, our VP is 'layered' with branching to the left (as one would expect for an OV structure). Arguments in favor of this kind of tree branching have been familiar since Ross (1969).

Now, in order to have a sufficient number of levels for later stating the inversion rules, we now recast the base rules just suggested for German (Dutch will be nearly identical) in terms of a more contemporary X-type syntax. For ease of exposition we have retained expansions containing an affix and stem parts as syntactic units. We are, however, convinced that a transformation-less, direct generation account along the line proposed by Gazdar, Pullum and Sag (1980) for English might also be possible. Our main aim here is not, however, to argue for the theoretically most satisfying base rules, but to point out the systematic variation among the various languages concerned and emphasize how the differences among them might have arisen.

(11)

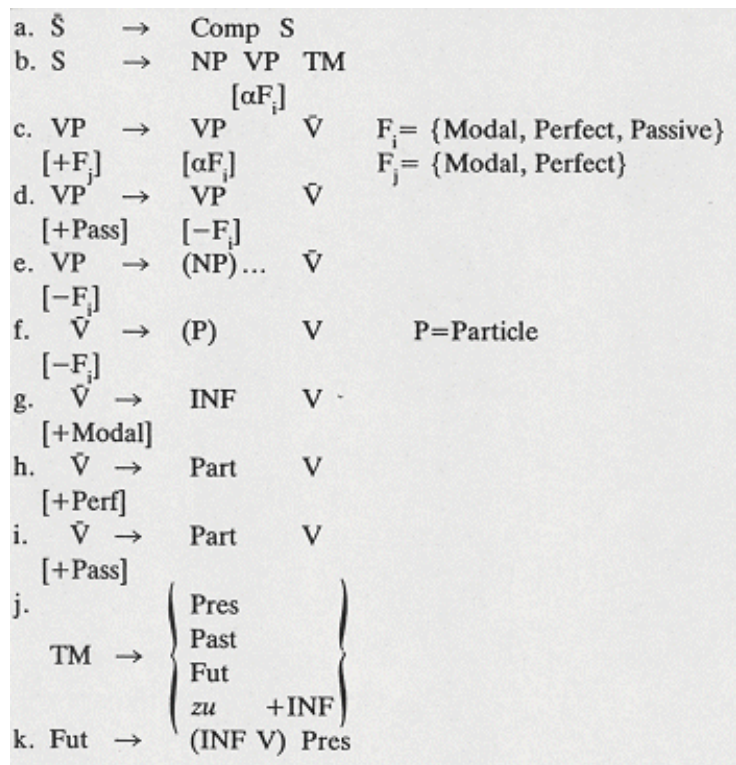


In addition to the rules in 11 two further assumptions must be made. First, the lexicon entries for verbs must be specified with the various subcategorization features. Thus,

(12)

a. $\vee=\{k o ̈ n n-$, müss-, soll-, woll-, dürf-, mög- $\}$

[+Modal]

b. $V=\{h a b-$, sei- $\}$

[+Perfect]

c. $V=\{$ werd- $\}$

[+Pass]

d. $V=\{$ werd- $\}$

[+Future]

Secondly and very importantly, we must assume a convention that features on dominating nodes spread down to the head of the phrase at the next lower level; such a Head Feature Convention or 'feature percolation' can be found in much recent transformational work, cf. Gazdar, Pullum and Sag (1980:5) for details. In this case the $\nabla$ and the $V$ in rules $(11 \mathrm{c}-11 \mathrm{e}$ ) and (Ilf-11i and $11 \mathrm{k})$ respectively, as heads, acquire the features on the dominating nodes to the left of the arrows. ${ }^{8}$ Thus, phrase markers as in 13 are generated.

(13)

a. dass Peter kommt.

that Peter comes.

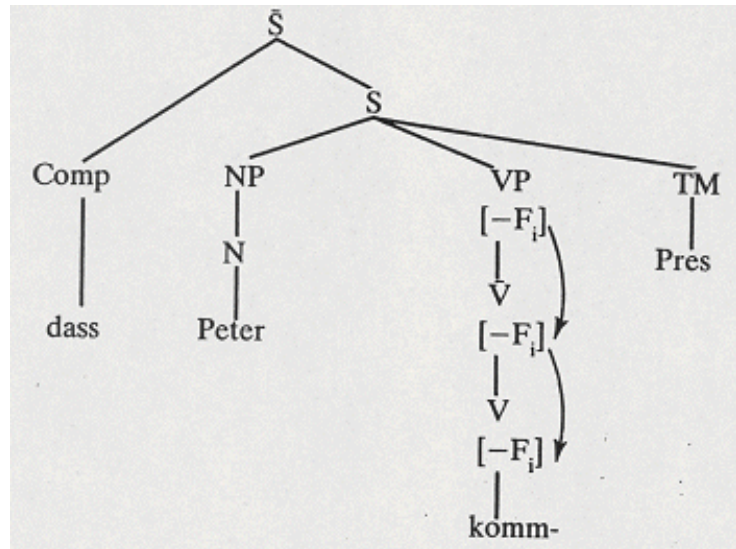


b. weil der Meister dirigieren können muss because the master conduct can must

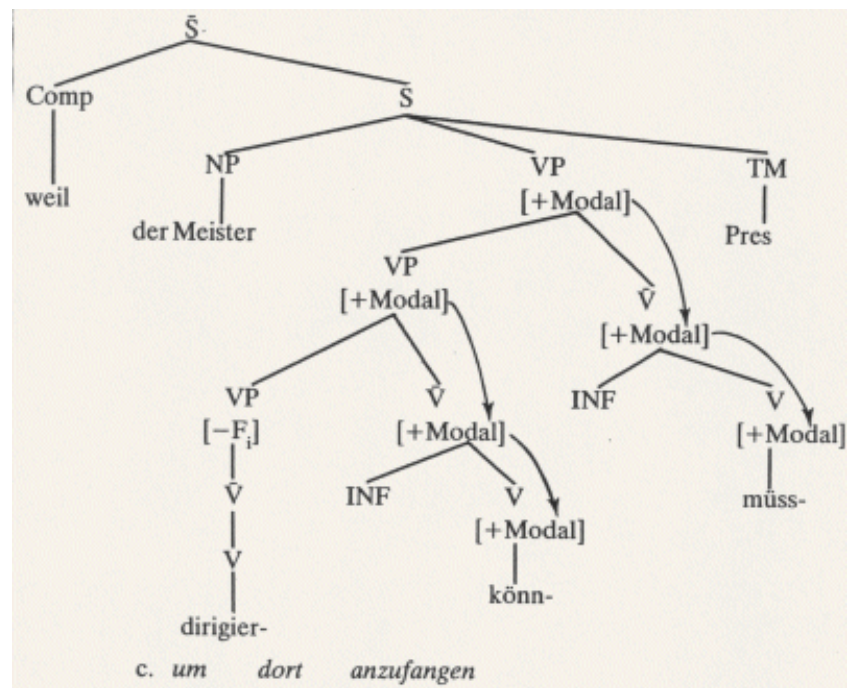
in order there to begin

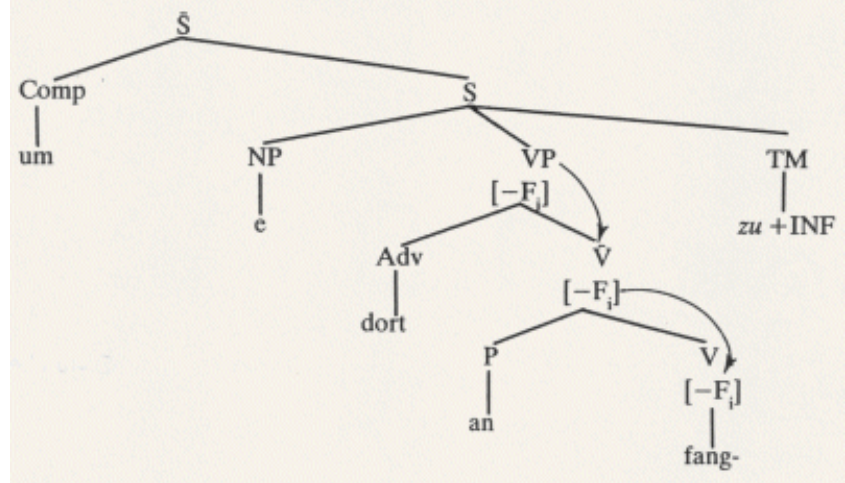


We now come to dealing with the DIC in German. As we have already noted, this construction occurs whenever there is a sequence:

(14)

\section{Main Verb INF+Modal PART+haben}

The syntactic symbol (or feature) PART is altered to INF and haben is moved to the left. At least, this series of changes represents a typical scenario. It does, however, not cover the instances differing somewhat from 14, cases that we feel give decisive insight into the mechanisms of the derivation. 15 represents one such example of the DIC that is particularly revealing, as it shows the grammatical process in development. The rules yielding the DIC are gradient in nature. Both $15 \mathrm{a}$ and $15 \mathrm{~b}$ occur in German with the same paradigmatic value, i.e. they fill the same paradigmatic slot, but with different stylistic and regional connotations.

(15)

a. weil er nicht anders hat können

b. weil er nicht anders gekonnt hat.

because he not otherwise can has (do).

$15 a$ counts as more strongly dialect colored, innovative, southern and regional, whereas $15 \mathrm{~b}$ represents the more conservative standard language. For those familiar with both structures an interesting coupling of FORM and POSITION is observed. If the participle is infinitivized (gekonnt $\rightarrow$ können, then inversion of the determining finite auxiliary hat is obligatory (gekonnt hat or hat können) as 16 shows. ${ }^{9}$

a. *weil er nicht anders können hat.

b. * weil er nicht anders hat gekonnt.

The lock step of INFINITIVIZATION and INVERSION is so characteristic that we feel any adequate account of the DIC must assign it a central role. Furthermore, the variation in the data here and in that yet to be illustrated, we feel, should also be accorded a determining role in the account. Labov (1969:737) once required 'that the study of variation add(s) to our knowledge of linguistic structure, and simplifies the situation rather than reducing the precision of the rules by uncontrolled and unaccountable notations.' Labov then goes on to introduce the notion VARIABLE RULE to capture the variation when... 'the rule is involved in the process of linguistic change.' (1969:738). Bailey (1973:13) augments Labov by postulating a single level of abstraction for all the systematic variation attested, '... whatever the level of abstraction represented by a grammar may be, it should contain underlying representations and rules which will generate all the systematic variation in 
the data at the systematic phonetic level of every lect abstracted from.' In this specific instance we will assume one underlying representation for all the systematic variants of the DIC we will describe; here intralinguistically for the southern, dialectal hat können vs. the northern gekonnt hat and later interlinguistically for the Dutch vs. German cases.

Let us begin by formulating INFINITIVIZATION for the two contexts so far encountered:

(17)

INFINITIVIZATION (first attempt)

$\mathrm{PART} \rightarrow \mathrm{INF} /\left(\mathrm{V}_{>}\right)$INF Modal ___ haben

The formalism in 17 corresponds to that found in the usual context sensitive rules. The parentheses around V, however, do not indicate that the alteration is to be carried out optionally. Rather they, along with the subscripted 'greater than' sign, signify that the presence of a verb will favor carrying out the rule. There could, for example, be speakers who execute INFINITIVIZATION only when INF Modal is preceded by a full verb, but others that do it even when no verb is present. Unlike Labov we employ only general tendencies (i.e. the greater than signs) instead of real statistical values or probabilities for the reason cited in Kay (1978). The rule 17 makes the following predictions:

$\begin{array}{lll}\text { underlying form } & \text { gekonnt hat } & \text { handeln gekonnt hat } \\ \text { Lect } 1 & \text { gekonnt hat } & \text { hat handeln können } \\ \text { Lect } 2 & \text { hat können } & \text { hat handeln können }\end{array}$

The rule 17 captures not only the various dialect forms but also clearly shows that lect 2 in 18 implies lect 1 . It predicts that there will not be a variety of German showing hat können that does not also have hat handeln können. Further, since lect 2 represents a variety of German showing the application of 17 'across the board', we can conclude that it corresponds to the historically original form, since a change is most general at the origin of change and as it spreads becomes weaker, assuming the wave model of progation of language change. ${ }^{10}$

Returning now to rule 17 , we point out that INFINITIVIZATION is much more widespread than this formulation would suggest. Today the participle assumes the paradigmatic shape of an infinitive not only for the six 
modal verbs but also for brauchen 'need', lassen 'cause, permit', the sensory verbs sehen 'see', hören 'hear' and helfen 'help' and in more archaic German pflegen 'accustom', machen 'make'; in Swiss German even anfangen 'begin', aufhören 'quit' and bleiben 'stay' as Lötscher (1978:3) reports. In Dutch the number of verbs in the slot occupied by Modal in rule 17 can include a great many items that are strictly unacceptable in German. Cf. below. However, here too the distribution is gradient. Erben (1967:54) notes first that the six modals must govern the Ersatzinfinitive (i.e. the DIC). But:

Auch bei brauchen und helfen tritt in dieser Konstruktion meist der 'Ersatzinfinitiv' ein (Also for brauchen and helfen the Ersatzinfinitiv usually occurs in this construction).

Bei anderen Verben schwankt der Sprachgebrauch, wenn gleich dort, z.B. bei fühlen, heissen, lehren, lernen, machen die eigentliche Partizipialform zu überwiegen scheint.

(For other verbs usage varies, although by fühlen 'feel', heissen 'call', lehren 'teach', lernen 'learn', machen 'make' the true participle form seems to dominate).

This variation is taken account of in 19

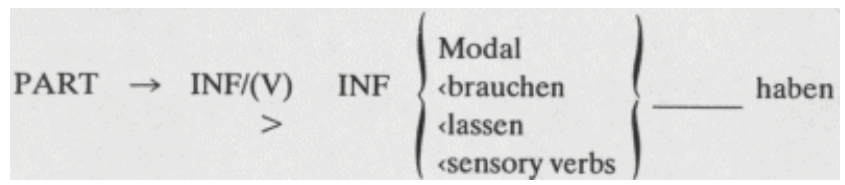

Once again, the notation in the braces requires an interpretation. The 'less than' signs indicate an implicational hierarchy that would normally be written as Modal < brauchen < lassen < sensory verbs. ${ }^{11}$ INFINITIVIZATION of a participle becomes increasing more obligatory as one procedes from right to left, from the least obligatory sensory verbs, to the most obligatory modal verbs. Rule 19 predicts a distribution of lects as follows: 
(20)

$\begin{array}{lll} & \text { WITH DEPENDENT } & \text { WITHOUT DEPENDENT } \\ & \text { INFINITIVE } & \text { INFINITIVE } \\ \text { most acceptable } & \text { hat kommen können } & \text { gekonnt hat/gebraucht } \\ \text { nicht hat (zu) } & \text { hat/gelassen hat/ } \\ \text { kommen brauchen } & \text { gesehen hat } \\ & \text { hat kommen lassen } & \\ & \text { hat kommen sehen } & \text { hat können } \\ & \text { kommen gesehen hat } & \text { hat brauchen } \\ & \text { kommen gelassen hat } & \\ & \text { nicht (zu) kommen } & \\ \text { gebraucht hat } & \\ \text { kommen gekonnt hat } & \text { hat lassen/hat sehen }\end{array}$

For the moment, the POSITION of elements is being disregarded and only the FORM, whether infinitive or participle, is under discussion, e.g. können or gekonnt. There are at least two factors working together in this rule and table, the influence of the individual infinitivized verb and the presence or absence of a preceding main verb. In actuality we are making a number of necessary simplifications, since fühlen 'feel' among the sensory verbs induces infinitivization with considerable less force than does sehen 'see' or hören 'hear'. Further simplification here is not differentiating between the relative strength of the two determining factors. Table 20 is supposed to indicate that forms in the lower right hand corner are assigned a much lower value than corresponding items on the left, which we interprete to mean that the factor preceding main verb counts for far more than the choice of auxiliary. Grimm (1969/1898:195) cites only cases with modal verbs, i.e.

(21)

a. das hat meine Emilia nicht wollen (gewollt)

that has my Emilia not want

(Lessing's Emilia Galotti)

b. hette mögen (gemocht)

would like

c. hette können (gekonnt)

would be able

d. darjegen heft de marggraff nicht khonen (nicht gekonnt)

against that has the margrave not can

Native speakers usually react to form like hat lassen/hat sehen with consterna- 
tion; while hat brauchen appears to be on the very extreme limit of the possible.

On the left hand side of the table all of the forms are at least conceivable. Yet, those we consulted found forms like kommen gekonnt hat quite impossible.

Nonetheless, unlike *hat lassen/* hat sehen, there are documented cases of it. Cf. Dal (1966:112):

(22)

a. Ich habe mitteilen gemusst. (Arndt)

I have communicate must

b. Hatte er die Reise nach Petersburg machen gewollt. (Arndt)

Had he the trip to Petersburg make want

c. Länger hatte sie nicht warten gewollt.

Longer had she not wait want

The rule also predicts that in 23 sehen or gesehen should both be possible, but that sehen will be given the nod in terms of acceptability. This is, of course, exactly what is found.

(23)

Da habe ich voriges Jahr den grossen Sumpf austrocknen sehen < gesehen.

Then have I last year the big swamp dry up see

Some dialects of German permit here only the participle, e.g. Middle Bavarian Willi Mayerthaler (p.c). And also, in the 18th and 19th centuries the participle was found even in finer literature.

a. Ich hatte dich kaum reden gehört (Goethe)

I had you scarcely speak heard

b. Ich habe niemand besser spielen gehört. (Heine)

I have no one better play heard

Predictably, the choice between lassen and gelassen should be easier to make. Sanders (1898:130) writes of this choice:

Ausser in dem Infinitiv Perfekti kommt von dem mit einem abhängigen Infinitiv verbundenen 'lassen' das Partizip in der Form 'gelassen' nur vereinzelt vor, wofür wir die folgenden Beispeile (aber durchaus nicht als Muster zur Nachahmung) anführen. (our emphasis).

(In addition to the infinitive perfect, there occurs a lassen with a dependent infinitive which appears from time to time in the participle form gelassen, for which we list the following examples but not as models to imitate.) 
(25)

a. Und die Handschuh, wo habt Ihr sie hängen gelassen (Goethe's Reineke Fuchs).

and the gloves where have you them hang left

b. Man hatte Alles weggetragen, nur das Köfferchen unschlüssig, in der Mitte des Zimmers stehen gelassen. (Goethe's Wahlverwandtschafteri).

One had everything carried off, only the small chest undecidedly in the middle of the room stand let

c. Etwas, das sie selbst auf eigene Hand sich ausgedacht oder sich einfallen gelassen haben (Fichte)

Something that they themselves on their own hand thought up or themselves occur let have

Finally, the choice between brauchen and gebraucht for most speakers is no choice at all. Of those we asked there was no doubt about intuitions, even with respect to attested examples of gebraucht such as

(26)

Er hätte nur die Regungen der eigenen Brust zu besingen gebraucht He would have only the stirring of his own breast to sing in praise need

All speakers questioned without exception preferred brauchen in 26 and in every other case with dependent infinitive.

Having illustrated the gradience in 18 we move on to some other traits. Rule 18 shows an interesting interaction with the rule placing $z u+I N F$ on the last element of the verbal complex. Consider, for example, how AUX-AFFIXATION will circumfix the complementizer $Z U+I N F$ to haben in 27.

a. Ich bin alt genug, die Entwicklungen verfolgen gekonnt zu haben

I am ald enough, the developments follow be able to have

b. verfolg- INF+könn- PART+hab- zu+INF $\rightarrow$

verfolg+INF könn+PART zu hab+INF

Normally, $z u+I N F$ is circumfixed to the last element and the $z u$ then inter- 
venes between haben and the model können. This affixed complementizer then effectively blocks INFINITIVIZATION from applying. It struck Grimm and Sanders and later also Reis that there are attested examples with a different and totally unexpected ordering of elements involving such infinitives clauses. For instance, 27 sometimes appear as 28 .

(28)

Ich bin alt genug, die Entwicklungen haben verfolgen zu können.

Here the $z u$ has simply been ignored and the infinitive clause treated as if it were finite. Another theoretically more interesting account of structures like 28 would be to assume a reordering of AUX-AFFIXATION and INFINITIVIZATION. In the usual case the affixation rule bleeds the subsequent INFINITIVIZATION rule. Speech errors have often been interpreted as reorderings, especially reorderings to the unmarked order. After both INFINITIVIZATION and INVERSION (to be discussed presently) have applied, only then are the complementizer zu and INF attached but in this case not to haben but to the product of the inversion, i.e. können. ${ }^{12}$

Another interesting reordering has been documented by Reis (1979:15) who reports on a sentence that appeared in the German news magazine Der Spiegel.

Eine Pariserin namens Dimanche soll sich ein gewaltiges Stirnhorn operativ entfernt haben lassen

A lady from Paris by the name of Dimanche is said (from) herself a great forehead horn by operation removed have let

instead of the normal

(30)

\section{haben entfernen lassen}

As in the previously discussed case haben has been repositioned to a spot in front of entfern-. Only then does AUX-AFFIXATION induce the participle marking onto entfern-. But, as above, the shifting of affixes must be reordered, i.e. delayed until haben has been moved to the right of entfern- ${ }^{13}$

Although it would be premature to put very much weight on just two such cases of reordering, it, nevertheless, suggests that in German an element induces a certain affix on a neighbor quite arbitrarily regardless of what it is. This behavior militates against the 'preprogramed' approach of direct generation by means of feature grammars. 
Further support for the kind of approach presented here in broad strokes comes from the interaction of other movement rules with 18. As soon as the main verb is removed from in front of the auxiliary modal by topicalization, a participle instead of an infinitive immediately becomes more acceptable. Our first observation about the gradience of 18 was that the presence of a full verb enhanced INFINITIVIZATION.

(31)

a. Schreiben hätte er wenigsten gekonnt or, of course, können.

Write would have he at least can

b. Er hätte wenigstens schreiben gekonnt.

$31 \mathrm{a}$ with a topicalized verb and gekonnt is significantly better than $31 \mathrm{~b}$ with a full verb in place untopicalized before the modal. ${ }^{14}$

A second argument comes from a particular variant of German, H.J. Sassé (p.c.). In German with a Saxon substrate some parts of the VP can be extraposed to the right of a modal verb. Though impossible in normative German, this construction will also bleed INFINITIVIZATION, as rule 19 predicts. Cf. this curious quote from Martin Luther, who employs both extraposed and non-extraposed alternatives in one single sentence.

Die Mutter hätte nicht GEDURFT [den Namen tragen], als wäre sie unrein, hätte auch nicht DÜRFEN [in Temple gehen]. (Luther)

The mother would have not should the name have borne as if were she impure would have also not should in the temple go

Finally, German permits the finite auxiliary haben to be omitted in poetic language in some dependent clauses. Since haben plays a crucial role in stating transformation 18 , removing it should and, as we have just demonstrated, does lower the obligatoriness of INFINITIVIZATION. Cf. the participles gekonnt in 33.

a. Wie er mich nicht wiederfinden gekonnt. (hat) (Chamisso)

As he me not find again could

b. Des Leids, das ich heilen gekonnt (habe) gedacht ich zu keiner Frist. (Freiligrath)

The suffering that I heal could pondered I at no time

In summary, eliminating either the main verb or the haben in rule 18 by means of topicalization, extraposition or deletion alters the class of candidate 
phrase markers to make them less eligible to undergo INFINITIVIZATION. This is as it should be according to the rule.

Having developed a scheme for constructing the appropriate FORMS in the German DIC, we now turn our attention to finding a characterization of the POSITIONS of the elements for this construction. The distribution first observed by Behaghel (1932:111-14) we feel, remains basically valid with some exceptions to be noted: (a) If haben is the finite verb, then it appears in front of the infinitive(s).

a. HEBBEN vinden unde horen laten.

have find and hear let

b. der ehe HAT schiessen wollen

who rather has shoot want

c. HÄTTE anders bestimmen lassen

would have otherwise decide let

(b) If werden is the finite verb governing modals, then it is inverted. If the governed verb is not a modal, there is no inversion.

(35)

a. wie er seine Gegner WÜRDE überwinden können

As he his opponents would conquer can

b. sich selbst WERDE helfen können

one's self would help can

vs.

(36)

a. dass er sitzen bleiben WIRD

that he seated remain will

b. dass wir schiessen hören WERDEN

that we shooting hear will

c. dass er sich schlafen legen WIRD

that he himself sleep lay will

(c) Should other verbs governing infinitives occur, then these can precede or follow.

The latter is the common practice in today's written language.

(37)

a. dich nit abführen lassen WÖLLEST

yourself not led away let would want

b. im anderen heulen hören KANN

besides cry hear can

c. dass man sich lieber von Preussen erobern lassen WILL.

that one oneself rather by Prussians conquer let will 
But also occassionally:

(38)

a. Die Lebensideen Goethes, die sich so nicht WOLLTEN vereinigen lassen

The great ideas of Goethe that themselves so not wanted unify let

b. det men sie nicht WOLDE gan laten

that one them not wanted go let

c. die sich mit keinen Worten WOLLTEN auflösen lassen

Who themselves with no words wanted disintegrate let

The rule effecting this positioning is clearly also of gradient nature: (a) haben obligatorily, (b) werden in some environments and (c) a modal usually not at all.

Behaghel's description, however, fails to be general enough to encompass all cases of inversion found in German. If more complex structures are considered, then not only the finite verb but also non-finite forms can and sometimes must be inverted. The Duden (1973:622) gives examples like 39.

(39) a. Er wird nicht HABEN kommen können.

He will not have come can

b. Er wird nicht kommen gekonnt haben.

He will not come can have

c. weil er nicht WIRD HABEN kommen können

because he not will have come can

d. weil er nicht kommen gekonnt haben wird

because he not come can have will

(capitalized forms have been inverted)

$39 a$ and $39 b$ as well as $39 c$ and $39 d$ represent in turn two paradigmatic variants of the future perfect of a modal (meaning 'He probably won't have been able to come.') in main and dependent clauses respectively. Of special interest here are 39a and $39 \mathrm{c}$. The two remaining forms $39 \mathrm{~b}$ and $39 \mathrm{~d}$ are very near the underlying structure; no DIC is present. 39a indicates that haben has been inverted even when it is not finite; in fact it must be inverted. As well, 39c shows that both wird and haben have undergone this rule. Leaving either of the two behind yields an unacceptable structure. 
(40)

a. * Er wird nicht kommen können HABEN.

b. * weil er nicht kommen können HABEN WIRD.

c. * weil er nicht WIRD kommen können HABEN.

d. * weil er nicht HABEN kommen können WIRD.

(Notice the positions of wird and haben).

The restrictions illustrated in 40 are valid only in those special cases in which INFINITIVIZATION has applied. Should, for example, a modal verb such as wollen instead of the perfect auxiliary haben occur in the environments illustrated in 40, then no inversion is necessary.

(41)

a. Er wird nicht tanzen können WOLLEN.

he will not dance can want

b. weil er nicht wird tanzen können WOLLEN.

Thus showing again the gradience that haben, even when not finite, will invert far more readily than a modal verb.

Aside from the inversions in these more complex structures, one also finds in most non-standard forms of German and frequently in older texts a more VO-like ordering in the verbal complex. 42c and 42d give examples from Middle High German.

(42)

a. Hätte mich nur das Schicksal in einer grossen Gegend HEISSEN wohnen. (Goethe).

would have me only fate in a great area command live

b. Er behauptet, er habe auch bei dem besten Willen da nicht KÖNNEN sich in Schweigen hüllen.

he claimed he has also in faith there not be able himself in silence cloak

c. durch welchen list hast du dass schif sus LASEN gan.

by what trick have you the ship so cause go

(Gottfried)

d. ich han dass HOEREN jehen. (Kudrun).

I have that hear say

Up to this point we have disregarded the place where the inverted element finally winds up and have concentrated our attention on which sub-categories of the verbal complex alter their position in the DIC. We now turn to discussing the actual location of such inverted elements. Behaghel's description again defines the usual position of inverted elements, immediately in 
front of the verb series. This is a position that sometimes separates off the main verb from its object complements. The sentences in 2 illustrated this architypical positioning for the Standard language. In southern dialects, especially Swiss German, the inverted form can occur much further to the left than one usually finds in more northern lects. Data from Lötscher (1978:8):

(43)

a. Mer händ em Hans WELEN es velo schänke töörffe. we have Hans want the bicycle give be allowed

b. Mer händ em Hans WELE TÖÖRFFEN es velo schänke.

Some of these examples will be discussed below.

The position of inverted items in the southern Standard language also deviates from the northern types. Generally, this kind of German is that employed when speaking or writing to outsiders, on radio and television, etc. and it will permit the finite auxiliary to exchange places with the last infinitive of a string. The motivation probably comes from an attempt to sound nondialect like, since the local varieties show no inversion whatsoever, Willi Mayerthaler (p.c.). Thus, in Middle Bavarian speaking territory, i.e. the broad band including Munich, Salzburg and Vienna, finite haben appears as follows:

(44)

a. weil er sich untersuchen lassen HAT wollen. because he himself examine have has want (instead of HAT untersuchen lassen wollen) b. weil er sie sprechen hören HAT können because he her speak hear has can (instead of HAT sprechen hören können).

Further to the South in the dialect area of Kärnten and Tyrolia with Southern Bavarian substrate, finite haben appears even further to the left, but still in positions different from that in typical northern speech. The conquorer of Mount Everest, Reinhold Messner from Tyrolia, once produced the sentence 45 in an interview on German television.

(45)

damit unser Lager von einer Lawine nicht getroffen HÄTTE werden können (instead of getroffen werden HÄTTE können

so that our camp by an avalanche not hit has be be able

(Middle Bavarian) or HÄTTE getroffen werden können (normative German)).

'So that our camp could not have been hit by an avalanche.' 
Before trying to develop a set of rules with proper weighting to guarantee generating not only the positions in the normative language but also showing how the rules for southern forms differ, we wish to expand the data under consideration to include Dutch examples. As we will see, Dutch shows an even more extreme type of inversion than any so far encountered. We will also want to argue for a particular kind of rule to carry out this inversion.

\section{Infinitivization and Inversion in Dutch}

The base rules one needs to posit for Dutch are nearly identical to those for German. Cf. 5 and 11 . We, nevertheless, present them in their entirity in order to be able to point out the differences.

(46)
a. $\overline{\mathrm{S}} \rightarrow$ Comp $\mathrm{S}$
b. $\mathrm{S} \rightarrow \mathrm{NP} \quad \mathrm{VP}$ TM
c. $\mathrm{VP} \rightarrow$ VP ${ }^{\left[\alpha \mathrm{F}_{\mathrm{i}}\right]} \vee \mathrm{F}_{\mathrm{i}}=\{$ Modal, Perfect, Passive $\}$
$\stackrel{\left[+\mathrm{F}_{\mathrm{k}}\right]}{\mathrm{VP}} \rightarrow \underset{\mathrm{VP}}{\left[\alpha \mathrm{F}_{\mathrm{i}}\right]} \quad \overline{\mathrm{V}} \quad \mathrm{F}_{\mathrm{k}}=\{$ Modal, Perfect $\}$
[+Pass $] \quad\left[-F_{i}\right]$

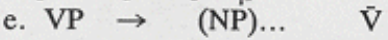
$\left[-\mathrm{F}_{\mathrm{i}}\right]$
f. $\hat{\mathrm{V}} \rightarrow \quad(\mathrm{P}) \quad \mathrm{V}$
$\left[-\mathrm{F}_{\mathrm{i}}\right]$
g. $\overline{\mathrm{V}} \rightarrow$ INF $\quad \mathrm{V}$
[+Modal]
h. $\bar{V} \rightarrow$ PART $\quad \mathrm{V}$
[+Perf]
i. $\overline{\mathrm{V}} \rightarrow$ PART $\mathrm{V}$
[+Pass]
j. TM $\rightarrow\left\{\begin{array}{l}\text { Pres } \\ \text { Past } \\ \text { te INF }\end{array}\right\}$

The lexicon will contain entries for the following subcategorized verbs.

(47)

V

[=Modal]

$\mathrm{V}$

[+Perf]

$\mathrm{V}$

[+Pass]
$\{$ kun-, moog-, moet-, wil-, zul-\}

\{heb-, zij-\}

$\{$ word- $\}$ 
We wish to emphasize again that $V$ and $\nabla$ in $46 c-46 i$ contain no features, because such features would be unnecessary. The convention 'feature percolation' will always project the feature from the VP or $\nabla$ onto its respective head $\nabla$ or $V$. Although there is near total agreement on which verb forms are periphrastic and which affixes are involved, there are also some fine points of difference. We list these without special comment.

The expected perfect form of the passive auxiliary in Dutch geworden is considered today to be old fashioned or non-standard. Instead of geworden zijn Dutch employs simply the single auxiliary zijn 'be'. Thus, one finds not $48 \mathrm{a}$ but $48 \mathrm{~b}$.

a. *Dit boek is door Querido uitgegeven geworden.

b. Dit boek is door Querido uitgegeven.

This book has been by Querido published

Secondly, the modal verb zullen is used to construct the periphrastic future in Dutch. It patterns syntactically like the other modals and doesn't show the defective paradigmatic features of German werden, which has no forms other than the present tense and the subjunctive.

Finally, as will be shown at length, INFINITIVIZATION in Dutch has been completely generalized and can no longer interact with movement rules such as topicalization or with the screening effect of the complementizer te, unlike the German $z u$.

Let us begin by noting that, parallel to German, a modal verb in the perfect with dependent infinitive always leads to the DIC. For this reason 49a with an infinitivized participle represents the only acceptable alternative. Failure to apply this rule yields an unacceptable sentence regardless of order.

a. dat hij het boek heeft kunnen lezen.

that he the book has be able read

b. *dat hij het boek heeft gekund lezen/gekund lezen heeft/lezen gekund heeft.

But, unlike German there is no gradience in the rule INFINITIVIZATION. Be it for modals like kunnen 'can, be able', semi-modals like hoeven 'need', the causative laten 'have, let' or verbs of sensory perception like zien 'see', no hierarchy of strength such as that found in 19 and 20 exists. In Dutch this rule is completely general and always must apply. A second difference must also be noted. Whereas more progressive dialects of German allow INFINITIVIZATION even when no dependent full verb complements accompany the modal, i.e. hat können as well as gekonnt hat, Dutch shows again categorial behavior. 
No such form as heeft kunnen or kunnen heeft but only gekund heeft or heeft gekund occurs. The Dutch table corresponding to the German data found in 20 would be:

(50)

\begin{tabular}{|c|c|c|}
\hline & WITH DEPENDENT & WITHOUT DEPENDENT \\
\hline & INFINITIVE & INFINITIVE \\
\hline most & heeft kunnen lezen & gekund heeft/heeft gekund \\
\hline \multirow[t]{9}{*}{ acceptable } & have can read & can have have be able \\
\hline & heeft hoeven gooien & \\
\hline & have need throw & \\
\hline & heeft laten maaien & \\
\hline & have let mow & \\
\hline & heeft zien maaien & \\
\hline & have see mow & \\
\hline & *heeft gezien maaien & $\begin{array}{l}\text { *heeft kunnen/*kunnen } \\
\text { heeft }\end{array}$ \\
\hline & ${ }^{*}$ heeft gelaten maaien & ${ }^{*}$ heeft hoeven \\
\hline least & ${ }^{*}$ heeft gehoeven gooien & *heeft laten \\
\hline acceptable & ${ }^{*}$ heeft gekund lezen & ${ }^{*}$ heeft zien \\
\hline
\end{tabular}

The lack of gradience in Dutch enables a much easier statement of INFINITIVIZATION than for the corresponding German cases. We begin with a rule recapitulating table 50 .

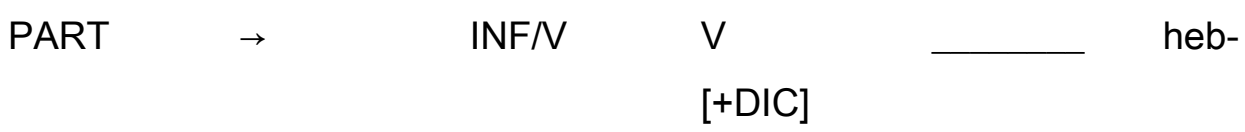

The symbol PART becomes INF whenever two verbs precede and heb-follows. The first of the preceding verbs must be one of the DIC verbs and therefore be able to induce an infinitive form on its nearest neighbor to the left. As with German, modals, semi-modals, causatives and sensory verbs fall in the subcategory

V

$[+\mathrm{DIC}]$

. But unlike German, the list of verbs to which this rule must apply is not limited to these cases. Indeed, we were able find very few verbs, if any, occuring in the

V

$[+\mathrm{DIC}]$ 
slot that would not cause the DIC. ${ }^{15}$ Therefore, the subcategorization feature [+DIC] can be eliminated from the rule altogether. The rule 51 must be written more generally to include such cases 
as: auxiliaries expressing inception (plus movement) and location (plus duration) such as INF gaan 'go, will, be going to', INF komen 'come, come in order to', te INF zitten 'sit', te INF staan 'stand' as well as INF zijn 'be' fit into the

$\mathrm{V}$

$[+\mathrm{DIC}]$

slot. ${ }^{16} \mathrm{Cf}$.

(52)

a. dat hij de stoel is GAAN halen/*is gegaan halen

that he the chair has go get

b. dat ze daar een hele tijd hebben STAAN praten/*hebben gestaan praten

that they there quite some time have stand talk

c. dat zij nog niet is WEZEN kijken/* is geweest kijken

that she yet not has be look

More interesting than these are the following relatively main verb-like instances that also partake in rule 51. To mention just a few: te INF weten 'be able to, know'; te INF durven 'dare to'; INF leren 'learn, teach'; INF helpen 'help'; te INF menen 'believe' and te INF proberen 'try'. For a more complete list of such verbs cf. Evers (1975).

(53)

a. dat zij het nooit heeft WETEN op te lossen/*heeft geweten op te lossen.

that she it never has be able to to solve

b. dat hij het nooit heeft DURVEN vragen/*heeft gedurfd (te) vragen

that he it never has dare ask

c. dat zij mij heeft LEREN paardrijden/*heeft geleerd paardrijden

that she me has teach horse ride

d. dat zij het heeft MENEN te moeten ontkennen/*heeft gemeend te moeten

ontkennen

that she it has think to must deny

Not only do there appear to be no exceptions to the rule INFINITIVIZATION in Dutch, we note further that some DIC verbs such as gaan must in the perfect be governed by the auxiliary zijn 'be' and not hebben 'have'. We can incorporate all of these new observations into a revised form of 51 , which we give here as 54 .

(54)

PART $\rightarrow$ INF/V (te) INF V $\longrightarrow\left\{\begin{array}{c}\text { heb } \\ \text { zij }\end{array}\right\}$ 
We have in passing pointed out that te doesn't influence INFINITIVIZATION in Dutch. This is another feature that makes the Dutch rule differ from its German counterpart. Example 27a illustrated the destructive effect of German zu on creating infinitives from participles. The Dutch infinitivization rule, for its part, is totally oblivious to the presence of such a te complementizer; only the infinitive is ever possible (with, of course, the Dutch ORDER of elements). Cf. 27a and 28.

(55)

Ik ben oud genoeg, om de ontwikkelingen te hebben KUNNEN volgen/*volgen gekund te hebben

I am old enough for the developments to have be able follow

Therefore, whereas the German morpheme zu can have syntactic influence on its surrounding, Dutch te is simply a prefix. For this reason reordering AUX-AFFIXATION and INFINITIVIZATION is simply not a possibility.

Since the elements INF and PART turn out to be mere inflection at the word level 54 can be simplified even further to a feature changing rule.

(56)

\begin{tabular}{|c|c|c|c|c|c|}
\hline \multicolumn{6}{|c|}{ INFINITIVIZATION } \\
\hline $\mathrm{X}$ & $-\frac{V}{[+I N F]}$ & $\frac{\mathrm{V}}{[+\mathrm{PART}]}$ & $\left\{\begin{array}{l}\text { heb-- } \\
\text { zij- }\end{array}\right\}$ & Y & \\
\hline 1 & 2 & 3 & 4 & 5 & $\Rightarrow$ \\
\hline 1 & 2 & $\begin{array}{c}3 \\
{[+\mathrm{INF}]}\end{array}$ & 4 & 5 & \\
\hline
\end{tabular}

In yet another way Dutch syntax is discrete where German is gradient. We have already noted that the presence of an infinitive to the left to the verb undergoing INFINITIVIZATION is obligatory in Dutch. Should extraposition or topicalization remove this infinitive from the verbal complex as in German examples 31 and 32, then we saw that the tendency to infinitivization in German only lessened. But, in Dutch, displacing complements by either of these movement rule destroys the environment for 56 totally; the infinitive simply may not be derived in such cases.

(57)

EXTRAPOSITION

dat hij mij VERBODEN heeft het boek mee te nemen/*het boek mee heeft

VERBIEDEN te nemen

that he me forbidden has the book along to take

(58)

TOPICALIZATION

Dansen (dat) heeft hij nooit gekund ${ }^{*}$ kunnen

Dance that has he never could 
Some typical and simple cases of the Dutch surface order include:

(59)

a. dat hij het heeft kunnen zien

that he it has can see

b. dat hij het heeft laten zien

that he it has let see

which should be compared with their German equivalents

(60)

a. dass er es hat sehen können

b. dass er es hat sehen lassen

Remembering that Frisian shows strict OV order, we can set up the following table of comparison of the three languages for simple cases

$\begin{array}{llll}\text { Frisian } & \text { MV } & \text { Aux }_{2} & \text { Tensed Aux } \\ \text { German } & \text { Tensed Aux } & \text { MV } & \text { Aux }_{2} \\ \text { Dutch } & \text { Tensed Aux } & \text { Aux }_{2} & \text { MV }\end{array}$

$$
\begin{aligned}
& M V=\text { main verb } \\
& \text { Aux }_{2}=\text { second auxiliary }
\end{aligned}
$$

In conclusion, the Dutch rule of infinitivization is less gradient than German; indeed it is nearly exceptionless with respect to the catalyzing environments. If any complement shows up to the left of a $\mathrm{V}$, then this verb will infinitivize as a result. This change pertains to all auxiliaries, verbs of perception and causation, as well as to some clear cases of main verbs. The issue of whether all main verbs require infinitivization can't be decisively settled here, since the lexicon apparently demands extraposition of their infinitive complements for some higher verbs and as we have just shown, such constructions always bleed the DIC.

We now turn our attention to the inversion of verbal elements in Dutch. In German the infinitivization of an auxiliary (or main verb) triggered a rule INVERSION, which would reverse the order of the auxiliary and the two (sometimes one) preceding infinitives. Examples in the previous section should have made it clear that a much more encompassing rule of inversion exists for Dutch. Dutch, like German and unlike Frisian, demands the inversion of the tensed auxiliary and unlike German also requires the inversion of 
$\mathrm{AUX}_{2}$ as well. This auxiliary may not be left in the underlying position. Cf.

(62)

${ }^{*}$ dat hij het heeft zien kunnen/zien laten.

Not only must Dutch invert the perfect auxiliary heb- but also the tensed modal verb, an alteration disfavored by German.

dat ik je kon horen huilen/*kon huilen horen/*horen huilenkon

that I you could hear cry

Even for verbal complexes whose highest verb has many main-verb properties, inversion is obligatory, e.g. cases with willen 'want' and proberen 'try'

a. dat men haar niet wilde laten gaan/ ${ }^{*}$ wilde gaan laten

that one her not wanted let go

b. dat hij het boek probeerde te laten verdwijnen/ ${ }^{*}$ probeerde verdwijnen te laten that he the book tried to let disappear

In all these instances the governing verb(s) obligatorily precede(s) the governed verb(s) (i.e. wilde before laten; probeerde before te laten). If there are two verbs present with or without intervening te-complementizers, then the inversion is almost exceptionless.

The alteration of order in Dutch (and German) auxiliaries in just these instances has been treated by Evers (1975) under the name of VERB RAISING, a schema that, as will be shown, involves more than just the order of elements. Since, in this section, we are interested first and foremost in discussing the environments for infinitivization and then it effects on the order of elements in surface structure, we postpone until later a detailed account of verb raising and continue to examine more facts about the order of elements in Dutch VP's.

The inversion of elements in German, as we now know, occurs basically whenever two infinitives (sometimes one) precede a third verb. There are, though, a number of significant factors making this rule gradient, e.g. what is the governing, 'highest' verb, what is the governing, right-most of the two infinitives and whether the complementizer zu intervenes. In Dutch we find that practically any two verbs in sequence will change places. Thus, leaving some details aside, one could write the structural descriptions of INVERSION as follows: 
(65)

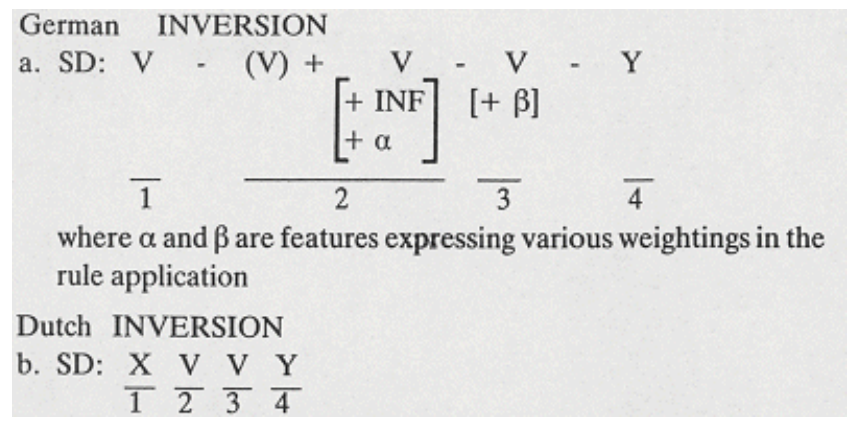

Again as before, Dutch has the most general form of the rule showing no sub-categorization features.

Contrary to what was just said though, Dutch does evidence some interesting variation, but variation of a quite different sort from that in German. Finite modal verbs governing a single infinitive may invert to VO-order only optionally. Should either of the two stated conditions, fail to hold, however, then inversion become obligatory. Cf. 66 vs. 67.

(66)

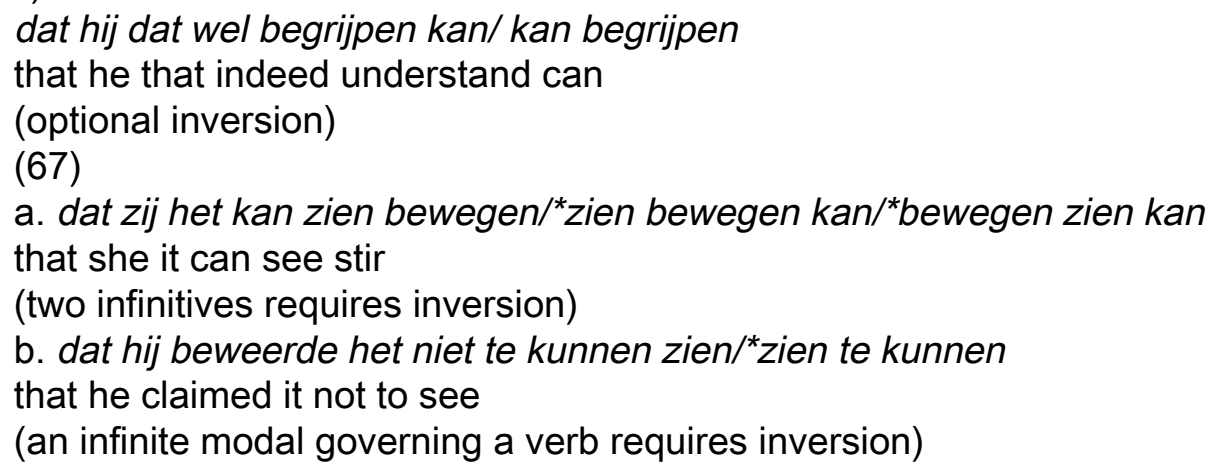

Interestingly, the variation of two verb complexes shows dependence on environment. The highest verb can exert determining influence on the strength of the inversion. A tensed modal with a single dependent infinitive allows the original underlying OV-order to be retained. 'Aspectual' auxiliaries like gaan 'go' also permit non-inversion. More main verb-like auxiliaries progressively show increasing tendency toward inversion. Semi-modals like hoeven 'need' and verbs of perception, for example, must undergo inversion. Heb-/zij- plus dependent past participle constitute an environment of only optional inversion. And this generalization holds irrespective of whether $h e b-/ z i j$ - is finite or infinite. 
(68)

a. dat hij gelachen heeft/heeft gelachen.

that he laughed has

b. dat hij beweerde niet gelachen te hebben/te hebben gelachen.

that he claimed not laughed to have

In fact, past participles can be left uninverted even in a sequence of several verbs or auxiliaries. The generalization to be made here is that the variation found in Dutch runs nearly antiparallel to that found in German along the dimension of 'auxiliariness': from hab-/heb- 'have' to werd-/zul- 'will' to the modals to the semi-modals like brauch-/hoev- 'need' to the causatives like lass-/laat- 'let, have' and finally to the verba sentiendi sehen/zien 'see', etc. Furthermore, the two languages are at odds along the dimension finite vs. infinite. We illustrate tendencies and antitendencies in inversion in the two languages with the following tables.

(69)

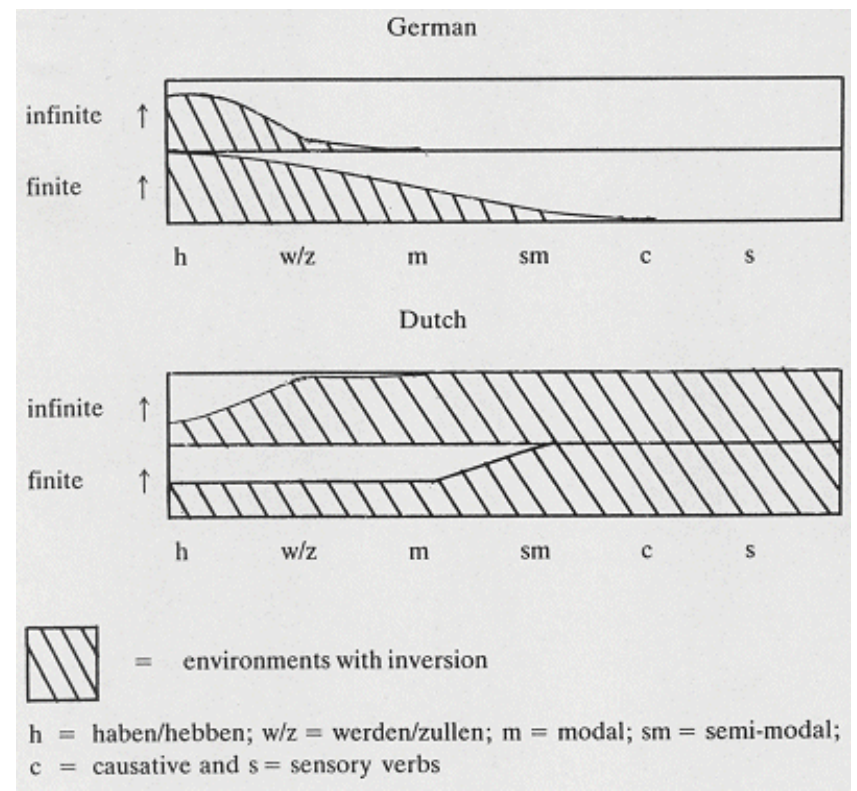


Again the two languages do not vary randomly but in a quite non-arbitrary manner. It would appear in this specific case that Dutch has generalized inversion everywhere and then allows the non-inversion in a few residual cases, i.e. with hebben and modals. German, being generally more conservative and more OV-like, still applies the inversion rule in those places of least resistance first, finite haben and werden. 17

As tempting as this account may be, further study is still necessary to confirm or disconfirm it. Some evidence in Dutch indicates that participles in fact may be moved by an entirely different process than that moving infinitives. If this should turn out to be the case, then perhaps it is misleading to compare data like 66, 67 and 68 to one another.

We now come to a topic mentioned only obliquely heretofor but left undiscussed in depth. The base rules for German and Dutch each contain an expansion $\nabla \rightarrow(P)$ $\mathrm{V} ; \mathrm{V}$ branches into an optional particle and $\mathrm{V}$. The particle $\mathrm{P}$ (traditionally called the SEPARABLE PREFIX) in the Continental Germanic languages has a clear independent syntactic status. Particles can, for example, be conjoined with and as in:

(70)

Er ging die Treppe herauf und herunter.

he went the stairs up and down

A further characteristic of separable prefixes like herauf and herunter in both languages is that in root sentences they get split from their verbs by the verb second rule, but attach to the verb in introduced dependent clauses as 71 shows.

(71)

a. dat hij morgen wat vroeger OPSTAAT.

dass er morgen etwas früher AUFSTEHT.

that he tomorrow somewhat earlier up gets.

(introduced dependent clause)

b. Hij STAAT morgen wat vroeger OP.

Er STEHT morgen etwas früher AUF.

he gets tomorrow somewhat earlier up.

(root clause)

Now it is interesting to note that particle splitting and the auxiliary inversion may interact in Dutch, but not in German. Or to put it differently, particles of separable compounds do not always accompany an infinitive when it is inverted, as the following examples show. ${ }^{18}$ 
(72)

a. dat hij wat vroeger OP wilde STAAN.

*dass er etwas früher AUF wollte STEHEN.

that he somewhat earlier up wanted to get

b. dat hij haar niet UIT liet SPREKEN.

*dass er sie nicht AUS liess SPRECHEN.

that he her not out let speak

c. dat hij haar niet liet UITSPREKEN.

dass er sie nicht AUSSPRECHEN liess.

The Dutch particle (cf. op and uit above) can even be stranded over more than one intervening verb. 73 gives an example with four verbs:

(73)

dat hij wel wat vroeger OP zou hebben kunnen STAAN

that he indeed somewhat earlier up would have be able get

zou hebben kunnen OPSTAAN.

Many regard the splitting of particles from their accompanying verbs as a typical special trait of northern, Hollandic Dutch; Belgian speakers are not fond of sentences like $72 \mathrm{a}, 72 \mathrm{~b}$ and 73 . The consequences of particle splitting for verb raising will be dealt with below.

\section{Verb Raising, Inversion and Variation}

In the past two sections we have analyzed the unexpected infinitive: FORM and the non-OV POSITION of elements in a family of structures called the DIC. We have assumed a gradient rule for German that alters the paradigmatic form PART into a form resembling the infinitive. For Dutch, this rule applies for all cases in the sequence infinitive plus participle plus heb-/zij-. For the second half of the DIC phenomena, inversion, we have stopped short of formulating adequate rules and have contented ourselves with making generalizations and listing the diverse and gradient conditions yielding the observed POSITIONS of the involved elements. It is now to the inversion, the structural change, to the inter and intralanguage variation and to the rules of VERB RAISING (VR) that we turn.

Evers (1975) was able to convincingly demonstrate the necessity of restructuring in the VP in the DIC. In brief, he shows with tests for constituent structure such as gapping that in the DIC the verbal elements at sentence end form a single, syntactic constituent, whether there is inversion of the members or not. For German, for instance, VR first restructures more or less as follows (details below): 
(74)
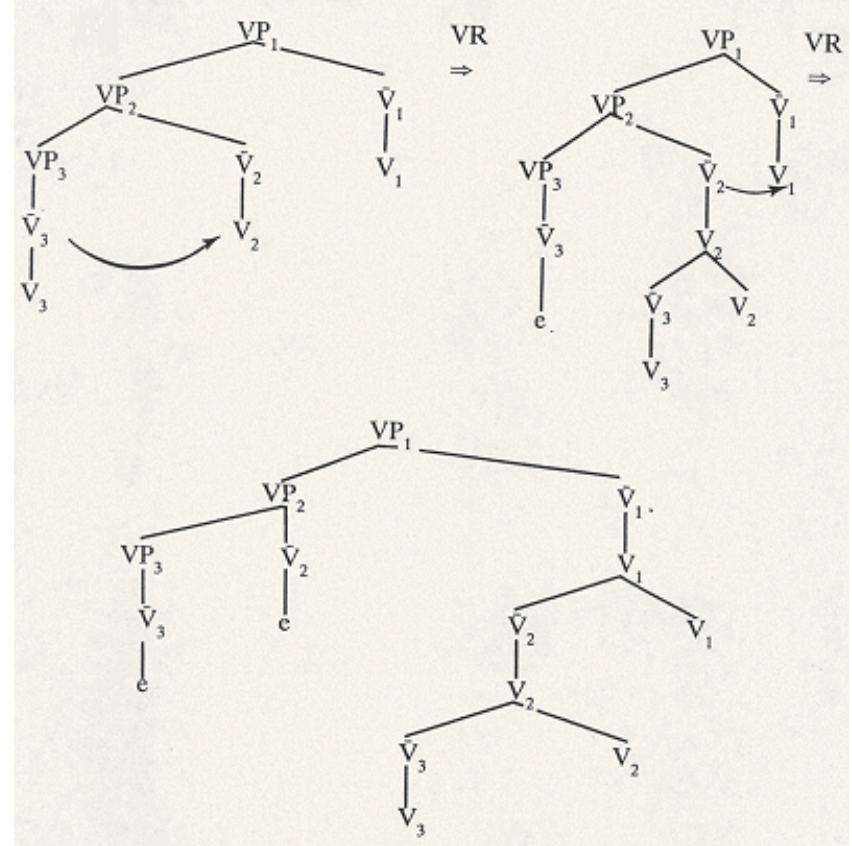

$A \nabla$ is Chomsky adjoined to the left of its governing verb/auxiliary, while AUX-AFFIXATION and INFINITIVIZATION carry out the different task of properly creating the correct paradigmatic forms in the given context. VR, for its part, generates a 'heavy' verbal cluster at sentence end. Finally, the rule of INVERSION (in German but not in Dutch) locally inverts the last two elements of this cluster. 
(75)

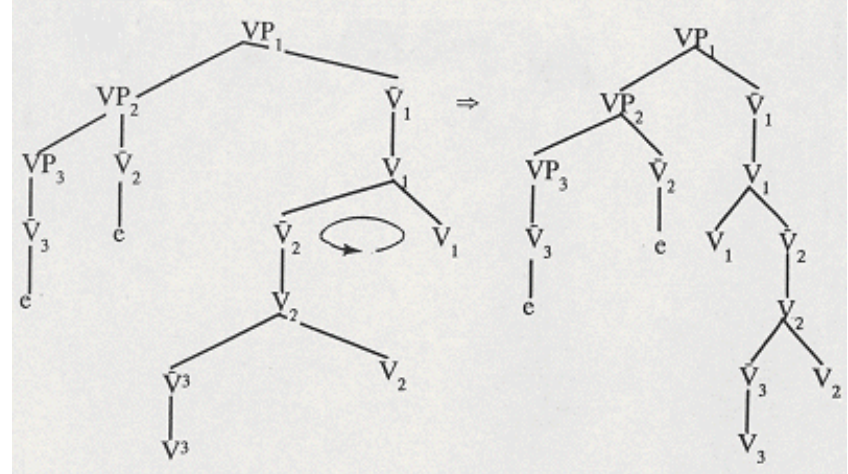

Significantly, both infinitivization and verb raising must feed inversion. Notice also that some kind of restructuring of the VP must be assumed in any case, since direct object NP's in the DIC are structurally cut off from the main verb and the other members of the verbal complex as we have repeatedly seen from the very first examples on.

In Dutch AUX-AFFIXATION and INFINITIVIZATION operate pretty much as in German. Only VERB RAISING and inversion may operate differently. Since, in Dutch, inverted elements occur pretty nearly 'across the board', there is really no reason to believe that two distinct rules still exist, inversion and verb raising in Dutch can be carried out simultaneously, as follows. Cf. 74 .

(76)

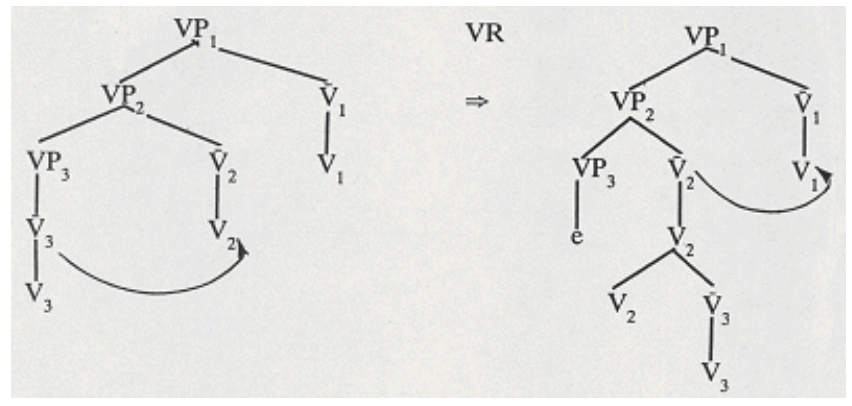




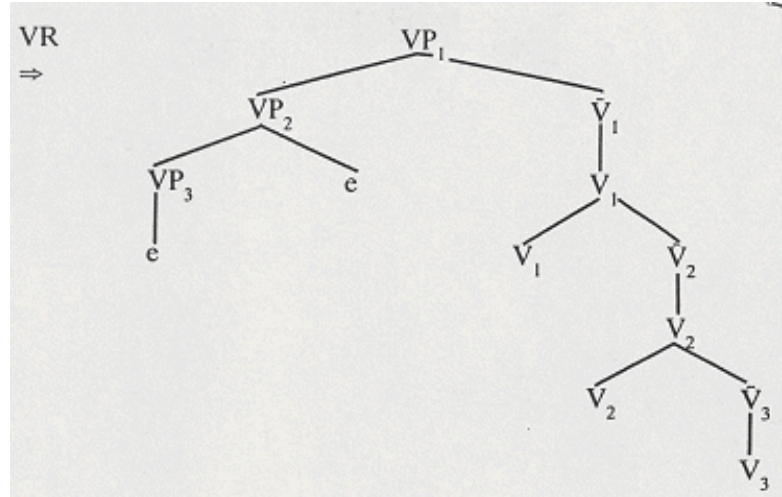

The $\nabla$ is Chomsky adjoined to the right of the neighbor element on its immediate right. Such a rule schema would generate the required 'across the board' inversion automatically.

We remember too that the German rule of INVERSION is a gradient rule sensitive to three things: (a) the highest verb, whether haben, werden or modal; (b) the second of two (or more) infinitives, whether haben

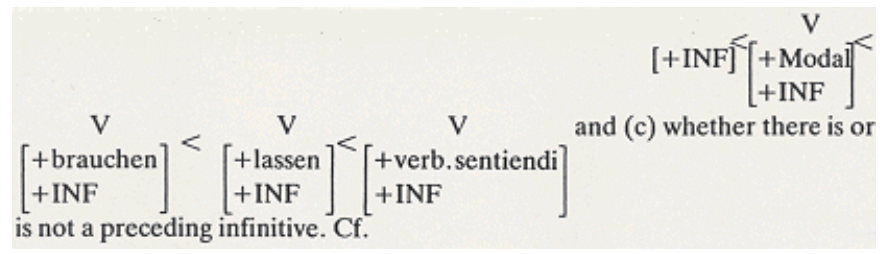


(77)

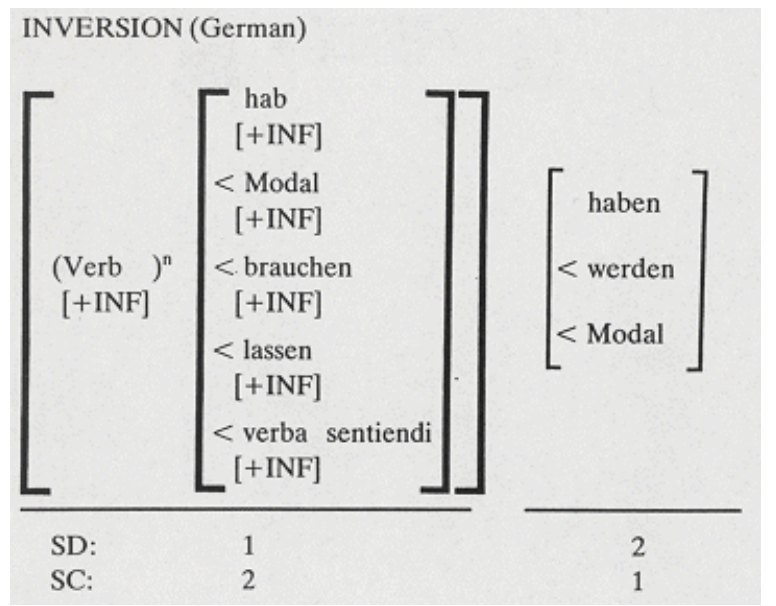

Let us hastely add that rule 77 has some interesting properties needing comment. We specify that this rule is to be a PERMUTIATION RULE and, thus, that 1 and 2 in the structural description must be sisters nodes. Furthermore, 77 belongs to the set of LOCAL RULES in the sense of Emonds (1976), a desirable rule type.

A further point should be made as well. The local rule 77 becomes possible for German only because restructuring by virtue of verb raising has preceded. A well-defined permulation rule is dependent upon the previous application of VR. This combination must be accorded great significance since both rules VR and INVERSION on this analysis have a place in Emonds typology of rules. Any other description would have the liability of not according with well-known and defined rule types.

Just as in rule 19 the catalyzing environment has been appropriately weighted to give various outputs, even if actual numerical values to the weights haven't been assigned. 77 and the verb raising schema can produce exactly the variation in normative German Behaghel describes.

Having dealt with the restructuring theme surfacing in Dutch and German, we now turn to the variation on this thema; how do the individual cases emerge out of this rule. Let us begin by regarding the derivation of structures found in the particle splitting dialects of Dutch, since this allows us to discuss the minor constituents in the entire verbal complex. 
In the spirit of the $X$ analysis and disregarding problems of non-parallelism among some category types and problems concerning the maximum number of levels per lexical projection, cf. Chomsky (1970:210) and Jackendoff (1977), we assign the sentence $78 \mathrm{a}$ the underlying analysis $78 \mathrm{~b}$ :

(78)

a. dat zij DOOR wilde GAAN/wilde DOORGAAN

that she on wanted go

b.

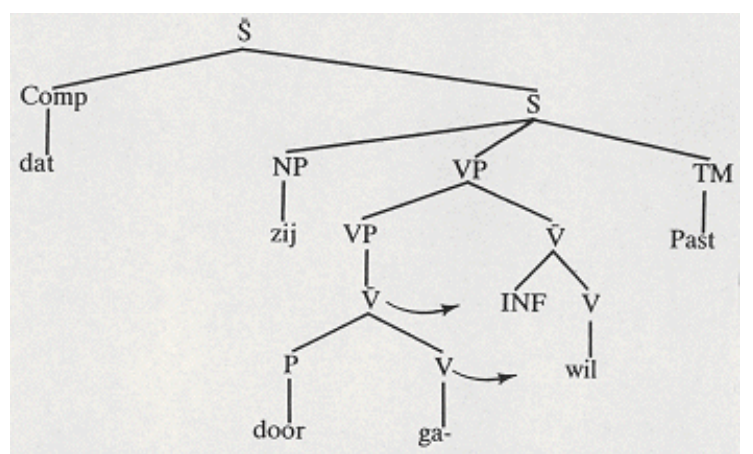

A great many details (such as some features) have been omitted to facilitate comprehending the structural changes. Once past and INF have been redistributed onto their neighbors, verb raising can take effect. Since, according to this dialect, either $\nabla$ doorgaan or just $V$ gaan can be right-adjoined, then either of the these two syntactic categories must satisfy the VR restructuring operation, i.e.

(79)

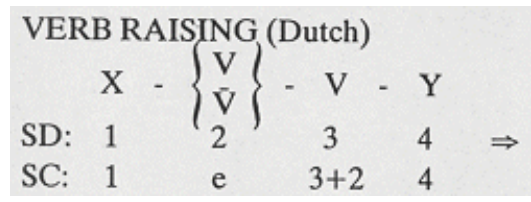

Rule 79 represents one of important ways German and Dutch, and for that matter, many of the non-standard variants of these two can differ. The rule for these language variants is basically identical (except for the side to which adjunction occurs) only the definition of constants in the statement of the transformation differ. German VR, for example, must apply only to $\nabla$ 's, as the derived phrase marker 80 sans INVERSION indicates. Cf. 78b. 
(80)

dass er hätte aufstehen können never * dass er auf HÄTTE stehen können

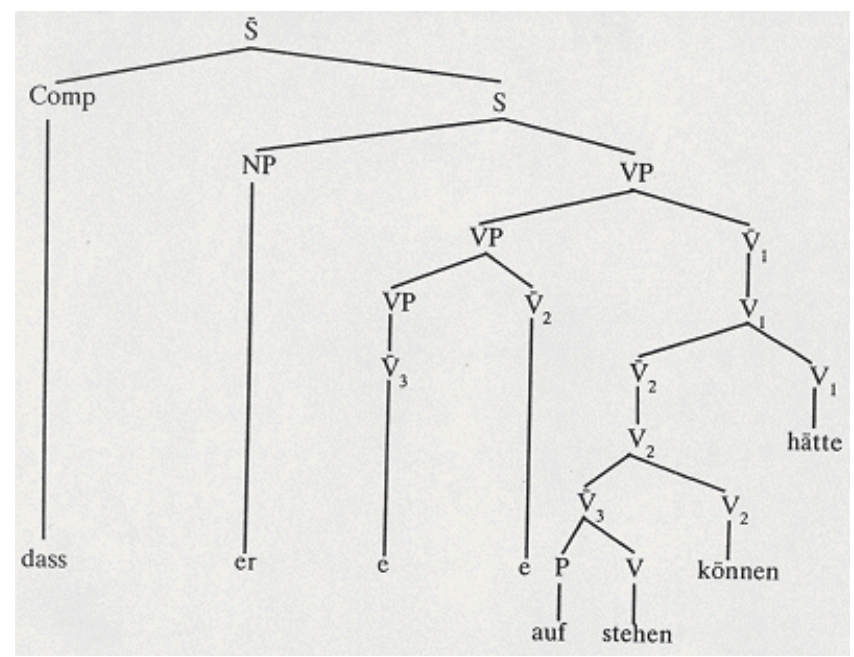

The inversion rule then reverses the sister nodes $V_{1}$ and the complex $\nabla_{2}$ to yield the surface form. As we see, the German VR rule differs from the Dutch by allowing only $\nabla$ 's to be raised.

(81)

VERB RAISING (German)

$\begin{array}{lllllll} & \mathrm{X} & - & \mathrm{V} & - & \mathrm{V} & - \\ \mathrm{SD}: & 1 & & 2 & 3 & \mathrm{Y} \\ \mathrm{SC}: & 1 & & \mathrm{e} & & 2+3 & 4\end{array}$

In this respect Belgian Dutch parallels German, since, as mentioned, speakers of southern dialects disfavor particle splitting. This characteristic feature of the South dovetails with other facts, because we know that until the 17th century both northern and southern forms of Dutch particle splitting are documented only very rarely. ${ }^{19}$ In fact, the northern forms of Dutch seems to have chosen to apply VR to progressively smaller and smaller VP subconstituents. The introduction of $V$ into 79 represents a general trend away from raising 'large' constituents, cf. Koelmans (1965). In 17th century 
Dutch, for example, even predicate nominals, adverbial phrases and direct objects (but not indirect objects) could be incorporated into verb raising. Contemporary Belgian nonstandard varieties, especially some dialects spoken in the provinces of West and East Flanders, still accept this kind of sentence. Vanacker (1970:157)

(82)

a. Zijn vader heeft hem 6 jaar (lang) laten [naar school gaan].

His father has him 6 years long let to school go

b. En ge zoudt nog moeten [uw eigen pintje betalen].

and you would yet have to your own beer pay

c. da'k snavonds moeste [mijn kousen afdoen].

that I that evening had to my stockings off pull

d. 'k zou met joenen auto kunnen [naar 't voetbal gaan]

I would with your car be ableto to the soccer match go

Now, data such as these and the non-incorporation of indirect ojrject NP's into VR must cause us to question the internal structure of the VP heretofor postulated.

Though it is still far from being unproblematic, such data argue for the assumption that the West-Germanic languages have a structural level between IO's and other units 'closer' to the verb such as the DO or adverbial phrases, a level at which the restrictions on VR can be stated. We assume, for example, a $\nabla$ level within the $\mathrm{VP} /\left[-\mathrm{F}_{\mathrm{i}}\right]$ that contains the 'narrower' complements of the verb and excludes the indirect object.

(83)

$$
\begin{aligned}
& \text { a. VP } \rightarrow \mathrm{NP} \ldots \nabla \\
& {\left[-\mathrm{F}_{\mathrm{i}}\right]} \\
& \text { b. } \nabla \rightarrow \mathrm{NP} \ldots \nabla \\
& {\left[-\mathrm{F}_{\mathrm{i}}\right]}
\end{aligned}
$$

Having enriched the VP structure, we can now perspicuously collapse the VR schema for northern, more innovative Dutch, which prefers raising small constituents, with the schema for southern, more conservative Dutch, which tends to invert larger VP chunks. 
(84)

VERB RAISING (Dutch panlectal)

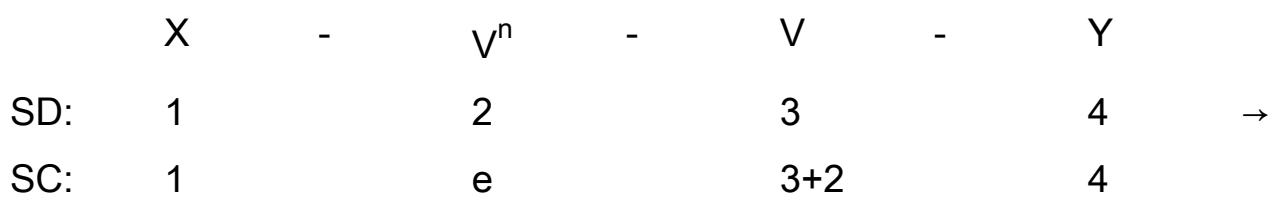

Conditions: Belgian Dutch $n=1$ E. and W. Flanders $n=1$ or 2; Hollandic Dutch $\mathrm{n}=1$ or 0 with a tendency to innovate toward smaller n-values.

German, on the other hand, seems to have fixed the lowest value of $n$ at 1 and with some exceptions to have set this as the highest value as well. However, marginally in the standard language and actively in the Alemannic dialects higher values of $n$ are found.

In a paper on word order phenomena in a large number of German dialects with special reference to Alemannic Lötscher (1978) presents a rich set of data on the problem under discussion here. Strikingly, Zurich Swiss German resembles in its order of verbal elements the Belgian dialects, both with respect to VR and the tendency toward a VO-verb complex. There are exceptions to this pattern, of course - participles always precede the temporal auxiliary, whereas a verb governing an infinitive may precede or follow it - but Lötscher regards these as rare and subject to still more restrictive conditions. ${ }^{20}$ Thus, we assume that Zurich German can be formalized as follows:

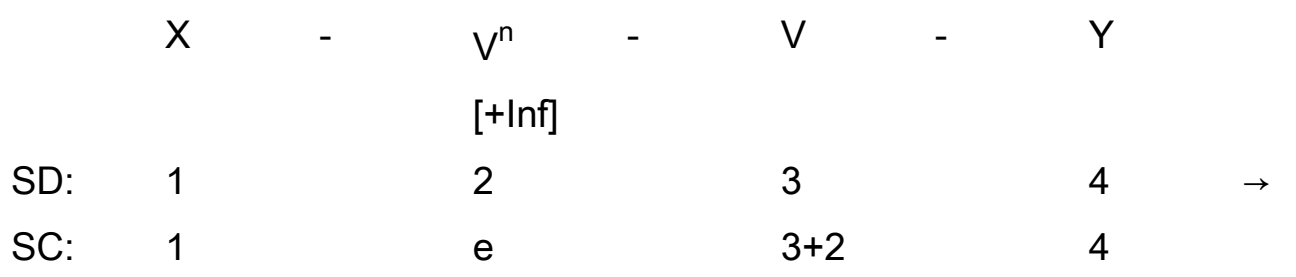

While rule 81 does not as yet cover all of the data in the verbal complex in Zurich German, it does allow us to consider what values $n$ may assume. In order to exemplify 85 we examine some Alemannic data. The following sentences 86 are all derivable from the underlying form 87.

(86)

a. Mer händ em Hans es velo schänke wele

We have Hans a bicycle give want

(Lötscher:(25))

b. Mer händ em Hans es velo wele schänke

(Lötscher:(25a'))

c. Mer händ em Hans wele es velo schänke

(Lötscher:(25b'))

d. Mer händ wele em Hans es velo schänke

(Lötscher:(25c')) 
(87)

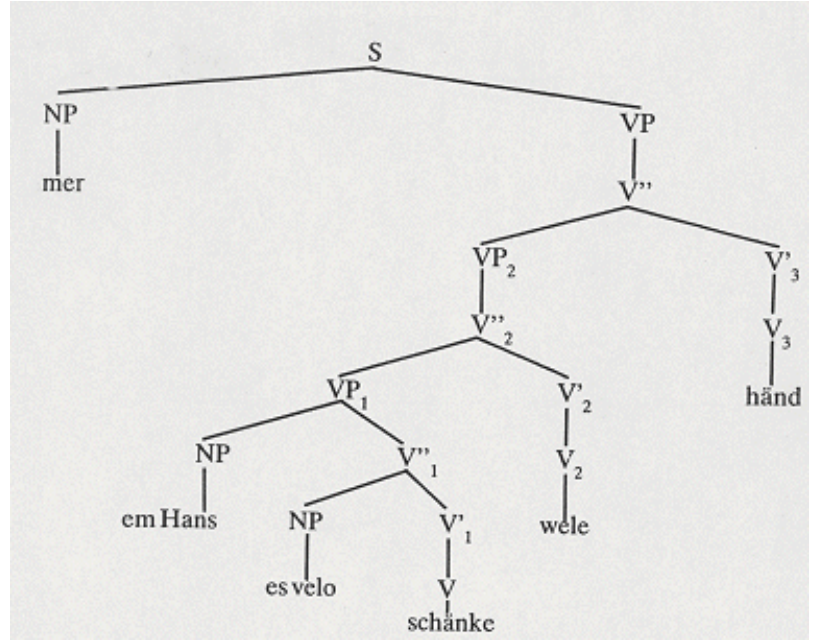

The verb second rule yields a sentence $86 a$, which represents a rare but possible order. $86 \mathrm{~b}$ through $86 \mathrm{~d}$ result from successively larger pieces of the VP being raised and right adjoined to nodes at different levels. 86b occurs, for example, when $\mathrm{V}_{1}{ }_{1}$ schänke is raised and adjoined to $\mathrm{V}_{2}$ wele; $86 \mathrm{c}$ is produced if, instead of $\mathrm{V}_{1}, \mathrm{~V}{ }_{1}$ es velo schänke is right-adjoined to $\mathrm{V}_{2}$; even $\mathrm{VP}_{1}\left(\mathrm{~V}^{\prime{ }^{\prime}}{ }_{1}\right)$ can apparently be raised, given sentences such as $86 \mathrm{~d}$, where em Hans es velo schänke is right-adjoined to $V_{2}$ wele. Thus, Zurich German has a VR rule accepting $n$-values on the $\mathrm{V}^{\mathrm{n}}$ from 1 to 3.

Finally, we would like to consider the question of what happens when the value of $n$ varies during a sequence of applications of VR. Consider the following underlying structure for a VP/[+Perf]. Again, AUX-AFFIXATION and INFINITIVIZATION have already taken place and subcategorization features have been omitted for ease of reading. 
(88)

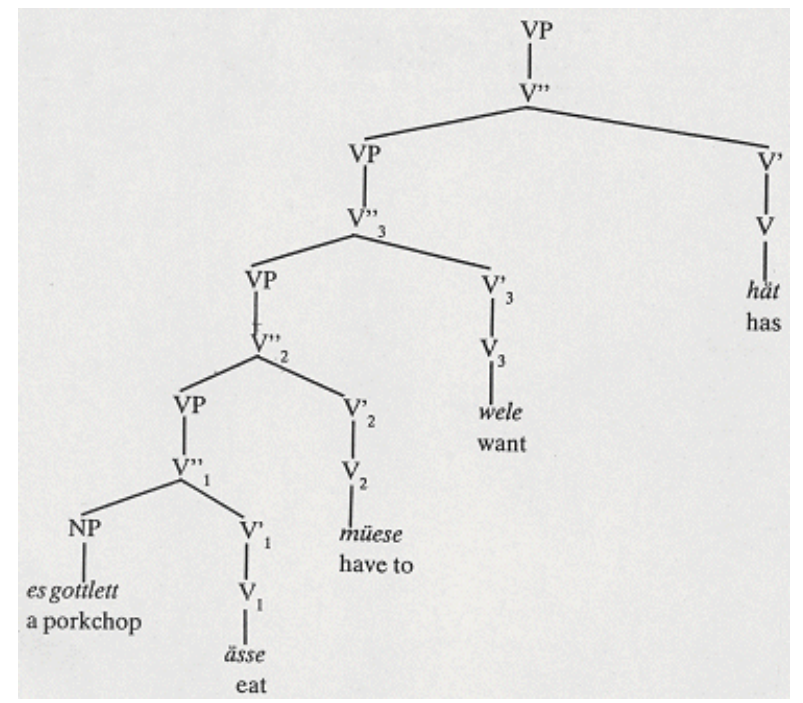

In the first application of VR either V' ${ }_{1}$ ässe or V" ${ }_{1}$ es gottlett ässe is raised to $V_{2}$ müese. Either of the following two sentences can be derived:

(89)

a. De Joggel hät es gottlett wele müesen [ässe] Jockel has a porkchop want have to eat

(Lötscher:(11a))

b. De Joggel hat wele müesen [es gottlett ässe] (Lötscher:(11c))

Suppose however, that after an initial VR of the $V_{1}{ }_{1}$ ässe to müese the second application of $\mathrm{VR}$ does not move $\mathrm{V}_{2}{ }_{2}$ but $\mathrm{V}_{2}$. In such instances a constituent with the following structure is raised

(90)

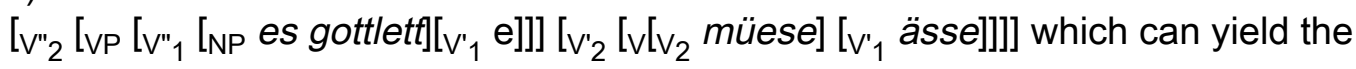
sentence:

(91)

De Joggel hät welen [es gottlett müesen ässe]

(Lötscher:(11b)) 
Thus, whereas an initial application of VR may leave behind parts of VP's, later applications of VR may drag these remnants along with a VR cluster. The above conclusion is confirmed by the existence of sentences in Zurich German like:

(92)

a. De Häiri hät wele syni chind la medizyn studiere Heinrich has want his child have (let) medizyn study (Lötscher:(20a))

but:

b. *De Häiri hät wele la syni chind medizyn studiere (Lötscher(20b))

Now, in order to treat these two structures, we need to make some assumption about la (lassen) - complements. Here, for the purposes of discussion we take it that an S-complement is involved. Nothing will, however, crucially depend upon this choice. The VP to which VR will apply is:

(93)

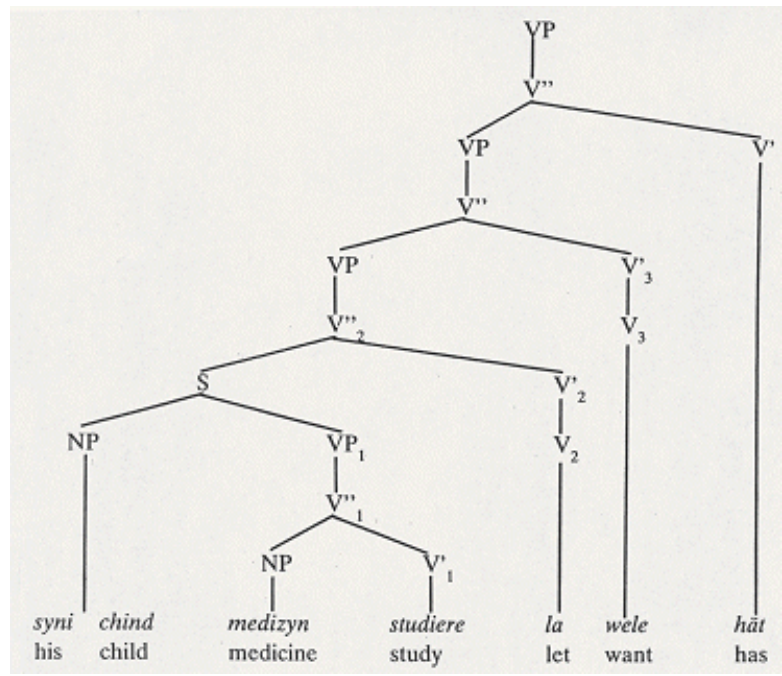


Given rule 85 the ungrammaticality of $92 \mathrm{~b}$ is predictable. The highest constituent that can be moved by VR on its first application is $\mathrm{VP}_{1}$ medizyn studiere. But, the $S$ syni chind medizyn studiere can not be raised. Similar conclusions follow if we were to assume that la subcategizes for NP + VP.

The derivation of example $92 \mathrm{a}$ is relatively simple and resembles the derivation of example 91 . The first application of Verb Raising results in V" ${ }_{1}$ (or VP ${ }_{1}$, that does not matter) being raised to the right of $V_{2} l a$. On the next application of VR it is not the $\mathrm{V}_{2}$ la medizyn studiere being raised but the dominating category $\mathrm{V}_{2}$ :

(94)

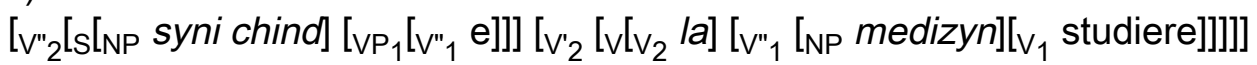

Thus, represented in a tree diagram, the following process takes place:

(95)

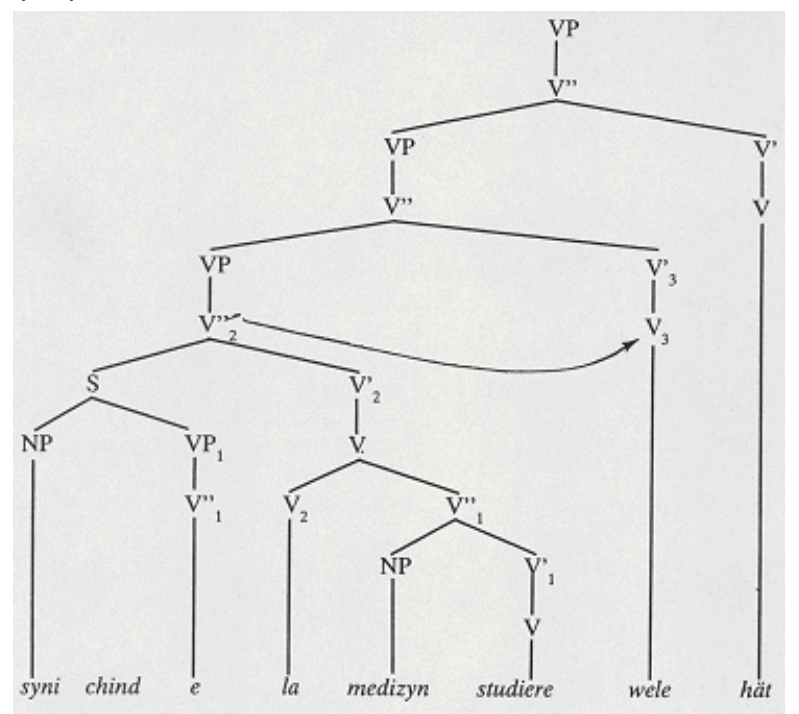

And eventually $92 a$ is derived. 
As we noted above, more could be said about the structure of the verbal complex in Zurich German. However, this paper is not meant to be a exhaustive reference grammar of the complete range of variation in the syntax of the verbal complex in West Germanic. We are fully aware of the fact that there are a number of phenomena that add to the variability of the verbal complex in West Germanic (including its semi-creolized variant Afrikaans). ${ }^{21}$ We believe, though, that with the above in part incomplete description of the verbal complex in Zurich German we have made the point we wanted to make; the seemingly chaotic variation in the verbal complex in West Germanic can be described in terms of a relatively simple set of rules with the potential for a surprisingly wide range of outputs.

\section{Summary and Conclusions}

We began this study by claiming that the Continental West-Germanic languages form a single syntactic system. In the course of the exposition we have tried to show how this claim is justified by developing an analysis assuming a single set of base rules and thus a nearly identical set of underlying forms. To such common underlying structures is subsequently applied a battery of gradient transformational operations. We consider it a significant finding that this gradience, both with respect to change of FORM and to change of POSITION of verbal elements, follows a definite pattern. On the basis of our evidence it appears that different auxiliaries show different reactive force in the face of linguistic change. The perfect auxiliary is the harbinger of linguistic transition, followed by the periphrastic marker of futurity, the modals being more resistant to these tendencies. Then, come causatives and the sensory verbs and, finally, full verbs begin to line up with the leaders, led in German by helfen, lehren, lernen etc. We pointed out further that finite more than infinite members of the verbal paradigm are inclined to change. In German, like the English modals for example, only the finite form of future-werden occurs.

Although we haven't argued directly for a position in the SOV-SVO controversy in Germanic, we conclude that the SOV position as majority pattern is more in harmony with the theoretical nature of language change. We noted, for example, that West-Frisian and Low German reveal the most verb-final traits, obliging the main verb or other governed auxiliary element to lead the governing auxiliary at sentence end - with the well-known exception of main clauses, where here as elsewhere in this family the tense bearing element serializes further to the left. The inversion and infinitivization facts indicate 
that the middle position on a scale of OV/VO properties belongs to the German Standard language (northern varieties), in which haben always, werden sometimes and modals rarely take a position to the left of their governing full verbs. Dutch and non-standard German varieties occupy a position of more pronounced VO-ness, with a more assertive minority OV pattern, having the most generalized, across-the-board rule application of infinitivization and verb raising. This evidence speaks for the following picture of wave-like spread of a change. Innovation began in the North and West of Germanic territory, passed a recalcitrant Frisian and Low German minority of this region unscathed and disseminated itself to the East and South, having, it seems, more success in the latter than the former named area. It first attacked the most auxiliary-like elements, and step by step encompassed other candidates for periphrasis and ultimately main verbs, until in Dutch no verb falling in the environment failed to be affected. There are, of course, a few perturbations in the propagation of these changes, interference from other waves of change. In Dutch a sequence of two verbs must occur in order that a participle become an infinitive and also a te complementizer is felt to offer no hindrance to the application of this rule. Another source of disturbance stems from the size of VP-chunk that becomes inverted. The more progressive northwestern and southeastern varieties, i.e. Hollandic Dutch and Bavarian, invert smaller chunks of VP, whereas German (northern varieties, and especially Alemannic and some Belgian dialects can permute nodes at higher syntactic levels.

In summary, we believe to have shown that for all their idiosyncracies, the West Germanic languages are much more similar than one might think, given the manifold and confusing diversity at the surface. Despite apparent and capricious variation that would seem to transfigure a constant syntactic theme, Dutch, German and Frisian are, in fact, what they have always been known to be, linguistic brothers under the skin. 


\section{Bibliography}

Akmajian, A., S. Steele and T. Wasow. 1979. The category AUX in universal grammar. Linguistic Inquiry 10.1-64.

Bach, Emmon. 1962. The order of elements in a transformational grammar of German. Language 38.363-69.

----. 1968. Nouns and noun phrases. Universals in linguistic theory, ed. by E. Bach and R. Harms, 91-124. New York: Holt, Rinehart and Winston.

Bailey, C.-J. N. 1973. Variation and linguistic theory. Washington: Center for Applied Linguistics.

Bech, Gunnar. 1955. Studien über das deutsche verbum infinitum. (Volume 1). KD VS 35, 2. Copenhague.

Behaghel, Otto. 1924. Deutsche Syntax. (Volume II). Heidelberg: Carl Winter Verlag.

----. 1932. Deutsche Syntax. (Volume IV). Heidelberg: Carl Winter Verlag. Besten, Hans den. 1981. A case filter for passives. Theory of Markedness in generative grammar. Proceedings of the 1979 GLOW Conference, ed. by A. Belletti, L. Brandi and L. Rizzi. Pisa: Scuola Normale Superiore, 65-122

Bickerton, Derek. 1971. Inherent variability and variable rules. Foundations of Language 7.457-492.

Bierwisch, Manfred. 1963. Grammatik des deutschen Verbs. (Studia Grammatica 2). Berlin: Akademie Verlag.

Chomsky, Noam. 1970. Remarks on nominalization. Readings in English transformational grammar, ed. by R. Jacobs and P. Rosenbaum, 184-221. ----. 1976. Conditions on rules of grammar. Linguistic Analysis 2.303-351. Dal, Ingerid. 1966. Kurze deutsche Syntax. Tübingen: Niemeyer Verlag. 
Duden. 1973. Grammatik (Volume IV). Mannheim, Wien and Zürich:

Bibliographisches Institut.

Edmondson, Jerold. 1980. Gradienz und die doppelte Infinitivkonstruktion.

Papiere zur Linguistik 22.59-82.

Emonds, Joseph. 1976. A transformational approach to English syntax. New York: Academic Press.

Erben, Johannes. 1976. Abriss der deutschen Grammatik. Berlin: Akademie Verlag.

Erdmann, Oskar. 1886. Grundzüge der deutschen Syntax nach ihrer geschichtlichen Entwicklung. (Volume I). Stuttgart: Verlag der J.G. Cotta'schen Buchhandlung.

Evers, Arnold. 1973. The syntactic motivation of predicate raising. Spektator 3.69-94.

----. 1975. The transformational cycle in Dutch and German. Indiana Univ. Ling. Club.

Gazdar, Gerald. 1980. Phrase structure grammar. Ms. University of Sussex. Gazdar, Gerald, Geoffrey Pullum and Ivan Sag. 1980. A phrase structure grammar of the English auxiliary system. (Available through Indiana University Linguistics Club 1981).

Grimm, Jakob. 1969/1898. Deutsche Grammatik (Volume IV). Hildesheim: Georg Olms Verlagsbuchhandlung.

Haan, Ger de. 1979. Conditions on rules. The proper balance between syntax and semantics. (Publications in Language Sciences 2). Dordrecht: Foris

Publications.

Hawkins, John. 1979. Implicational universals as predictors of word order change. Language 55.618-48.

Helten, W.L. van. 1892. Bijdragen tot de Dietsche Grammatica, 28: Over het gebruik van een infinitief in plaats van 't Partic. perf. ter omschrijving van een verleden tijd. Tijdschrift voor Nederlandsche Taal- en Letterkunde 11.168-77. Hoeksema, Jack. 1980. Verbale verstrengeling ontstrengeld. Spektator 10.221-49.

Hoekstra, T. and M. Moortgat. 1979. Passief en het lexicon. Forum der Letteren 20.137-61.

Jackendoff, Ray. 1977. X syntax. A study in phrase structure. Cambridge: MIT Press.

Kay, Paul. 1978. Variable rule, community grammar and linguistic change. Linguistic variation: Models and methods, Ed. D. Sankoff. New York: Academic Press. 
Kern, J.H. 1912. De met het Participium Praeteriti omschreven Werkwoordsvormen in 't Nederlands. Johannes Müller, Amsterdam. Verhandelingen der Koninklijke Akademie van Wetenschappen te Amsterdam. Af deeling Letterkunde. Nieuwe Reeks. Deel 12, No. 2.

Koelmans, L. 1965. lets over de woordvolgorde bij samengestelde predikaten in het Nederlands. Nieuwe Taalgids 58.156-65.

Kohrt, Manfred. 1979. Verbstellung und 'Doppelter Infinitiv' im Deutschen. Leuvense Bijdragen 68.1-31.

Koster, Jan. 1975. Dutch as an SOV language. Linguistic Analysis 1.111-36. Labov, William. 1969. Contraction, deletion and inherent variability of the English copula. Language 45.715-62.

Lange, Klaus-Peter. 1981. Warum Ersatzinfinitiv? Groninger Arbeiten zur Germanistischen Linguistik 19.62-81.

Lehmann, Winfred. 1971. On the rise of SOV patterns in New High German. Grammatik Kybernetik Kommunikation (Festschrift Alfred Hoppe), ed. by K. Schweisthal, 19-24. Bonn: Dümmler.

----. 1972. Proto Germanic syntax. Toward a grammar of Proto Germanic, ed. by F. van Coetsem, H. Kufner, 239-68. Tübingen: Niemeyer Verlag.

Lockwood, W.B. 1968. Historical German syntax. Oxford at Clarendon Press. Loey, A. van. 1970. Schönfelds Historische Grammatica van het Nederlands. Klankleer, vormleer, woordvorming. 8e druk. N.V. W.J. Thieme \& Cie.: Zutphen. Lötscher, Andreas. 1978. Zur Verbstellung im Zürichdeutschen und in anderen Varianten des Deutschen. Zeitschrift für Dialektologie und Linguistik 45.1-29. Naro, Anthony. 1981. The social and structural dimensions of a syntactic change. Language 57.63-98.

Nieuwenhuijsen, P. 1975. Review of Evers 1965. Spektator 5.589-602.

Paul, Hermann. 1968/1920. Deutsche Grammatik. Tübingen: Niemeyer Verlag. Pauwels, A. 1953. De plaats van hulpwerkwoord, verleden deelwoord en infinitief in de Nederlandse bijzin. Leuven.

Pauwels, J.L. 1965. De volgorde van verbogen verbale vormen in het Nederlands. Dietse Studies, ed. by E. Lindenberg, E. Raidt and J.A. Verhage. Academica: Capetown and Pretoria/Van Gorcum \& Comp. N.V./Dr. J.J. Prakke and H.M.G. Prakke, 105-110.

----. 1970. Statistisch onderzoek van de Nederlandse zinsbouw. Nieuwe Taalgids (Van Haeringen nummer) 93-100. 
Ponelis, F.A. 1979. Afrikaanse Sintaksis. Pretoria: J.L. van Schaik (Edms) Bpk. Popper, Karl. 1962. The open society and its enemies. New York: Harper Torchbooks.

Reis, Marga. 1974. Syntaktische Hauptsatz-Privilegien und das Problem der deutschen Wortstellung. Zeitschrift für Germanistische Linguistik. 2.299-327. ----- 1979. Ansätze zu'einer realistischen Grammatik. Befund und Deutung. (Festschrift Hans Fromm), 1-21. Tübingen: Niemeyer Verlag.

Riemsdijk, H.C. van. 1978. A casestudy in syntactic markedness: The binding nature of prepositional phrases. (Studies in Generative Grammar 4). Dordrecht: Foris Publications.

Ross, John R. 1969. Auxiliaries as main verbs. Studies in philosophical linguistics, ed. by W. Todd, 77-102. Evanston: Great Expectations.

Sanders, Daniel. 1898. Satzbau und Wortfolge in der deutschen Sprache. Weimar: Verlag von Emil Felber.

Steele, Susan. 1975. On some factors that affect and effect word order. Word order and word order change, ed. by C. Li. Austin: University of Texas Press. Stroop, J. 1970. Systeem in gesproken werkwoordsgroepen. Taal en Tongval 22.128-47.

Vanacker, V. 1970. Een 'Zuidnederlandse' konstruktie in een paar Zuidnederlandse dialekten. Nieuwe Taalgids (Van Haeringen-nummer) 140-57. Vennemann, Theo. 1974. Topics, subjects and word order studies: from SXV to SVX via TVX. Historical linguistics, ed. by J. Andersen and C. Jones.

Amsterdam: North-Holland.

----. 1975. An explanation of drift. Word order and word order change, ed. by

C. Li. Austin: University of Texas Press.

Wunderlich, Hermann, and Hans Reis. 1924. Der deutsche Satzbau. (Volume I). Stuttgart/Berlin. J.G. Cotta'sche Buchhandlung Nachfolger.

Zwarts, F. 1975. Some remarks on the linear cycle in Dutch syntax. Ms.

University of Amsterdam.

\section{Eindnoten:}

1 Accounts of the history of the DIC are at best confusing. With respect to its origin two hypotheses can be found in the literature. Lachmann and Grimm as well as many successors have held the HOMOPHONY HYPOTHESIS, seeing the seed of change in the identity of the prefixless past participle, especially of the verb lassen 'let', which into the Middle High German period was lāzen, lān, and the infinitive. Less common has been the ASSIMILATION HYPOTHESIS, held largely by critics of the first view, cf. for example Erdmann (1886). This latter analysis assumed that a participle form came to take the shape of its surrounding Infinitival environment. Wunderlich and Reis (1924:298-307) claim that the 19th-century German philologist Lachmann was the first to propose the hypothesis that the origin of the DIC could be found in prefixless strong participles of some verbs. Speakers then mistook the participle for the infinitive and the rule was carried over onto other verbs, '..deren Part. Prät. ebenfalls ohne ge- mit dem Infinitiv gleich lauteten, wie heissen, sehen und pflegen (mhd. Part. Prät. gepflegen). (...whose past participles without ge- would also be formed identically to the infinitive), Dal (1966:113). Grimm embraced Lachmann's hypothesis in so far as können, sollen, wollen, mögen, müssen, dürfen, heissen, lassen and sehen are concerned - all of which are supposed to have had strong participles (those ending in -en) as well as weak ones (those ending in $-t$ ). According to Grimm helfen, hören, lehren, lernen and fühlen were added to the DIC class a little later. 
The data presented by Erdmann (1886), Kern (1912) for Dutch and Behaghel (1924), do not fully support the HOMOPHONY HYPOTHESIS. Wunderlich and Reis (1924) also note that in a study by Kurrelmeyer it was found that the infinitivus pro participio occurred for tun, helfen, hören, heissen, lassen and somewhat later for sehen, müssen and türren. Not until the 15th century is the DIC attested for verbs such as mögen, wollen, können, sollen and dürfen. Erdmann (1886:110-111) points out that the Lachmann/Grimm account leads to wrong predictions, since only the prefixless past participles of sehen, lazen and heizen would yield the requisite identity with infinitives, i.e. (ge)sehen, (ge)lazen, (ge)heizen. Other forms of so-called preterito-presentia fail to be identical because of vowel differences, cf. (ge)kunnen instead of the usual gekonnt, (ge)wizzen instead of gewusst and that some strong verbs with the DIC today would never have had identical participles and infinitives because of Ablaut, cf. helfen vs. (ge)holfen. Behaghel (1924) and Kern (1912:46-53) notice further difficulties. Behaghel claims that the Old High German past participle of lazen was gilazan and lazan is never attested. Kern, however, doesn't wish to exclude the possibility of this unattested form (parallel to heizen). He adds, though, that the ge-prefixed past participle is the original one and that only a limited number of past participles could pass unprefixed. Furthermore, Kern demonstrates that even a revised homophony account based upon lassen and heissen does not work for Dutch, which already had a richly developed DIC in the 13th century. Without exception the past participles of laten and heten in Middle Dutch were gelaten and geheten and still the infinitives is the normal form in the DIC construction. Furthermore, preterito-presentia also required ge- as participles and yet showed up as infinitives in the DIC. Kern bases his account upon data collected by Van Helten (1892). This latter named study shows that the DIC sometimes gave rise to unoriginal participles such as gewillen, instead of the usual participle gewilt (willen).

It seems to us, given this impressive array of arguments, that the HOMOPHONY HYPOTHESIS has been severly challenged and requires new evidence if it is to be retained at all. We find it quite impossible to decide from the attested cases which of the two hypotheses is more convincing and what environments might have initiated the change. It does seem to us, however, that Dutch was ahead of German in general.

The results of the study we are presenting in this paper probably favor the ASSIMILATION HYPOTHESIS to the extent that an infinitive environment for the rule is needed. In one sense our account remains at odds with the historical data. We predict on the grounds of present-day variation that the modal verbs of German were the first to undergo the change and the sensory verbs the last. This chronology is not supported by the order of first citations in documents. Yet, the historical sources are often manuscripts that have gone through the hands of many scribes from many different areas. The reliability of such sources must be in doubt. So much for the history of the FORM of the DIC.

Our account does shed light on the history of the POSITION of elements in the DIC. The German data show us that the unexpected position results most likely for haben and less likely for werden and the modals. As Naro (1981) has shown for Brazilian Portuguese syntactic change often begins in the most salient environment. Identity of FORM of participle and infinitive would be most conducive to change, since here the opacity of FORM is at its greatest, as Grimm said 'the true infinitive here would be counterintuitive'; a change in syntax then marks the form that has become opaque. Also, the nature of some of these historical changes may have been clouded by reanalysis. In fact, VERB RAISING seems in some cases to be just such a rule.

2 Reis, in our opinion, is employing 'core grammar' in a sense that apparently differs from that in Chomsky (1976).

3 Implicit in the frustration of Kohrt and Reis rests the idea that variation complicates and weakens an analysis. Yet, Labov's work has made clear that the opposite should be true. Indeed, two approaches have been proposed to incorporate language variation into linguistic theory: (a) the wave model-implicational scale treatment advocated by Bailey (1973) and Bickerton (1971) and (b) the variable rule-as-community grammar treatment found in diverse forms in Labov's writing, cf. Kay (1978) for comparison and discussion. In dealing with variation in German and to a lesser degree in Dutch we have made use of the former, since this model predicts that variation will occur only at the leading edge of change and that lects already having been 'rolled over' by the change will show only categorial behavior. This is just what is found.

4 Hoeksema (1980) represents an approach to VERB RAISING and the DIC in Dutch from a non-transformational perspective. He uses Gazdar's (1980) metarule concept in order to write 'multiplication rules'.

5 The only cases of the DIC in our Frisian corpus involve the governing verbs skyne 'appear, seem' and begjinne 'begin'.

6 We ignore here the necessary expansions for verbal complements.

7 Notice that the inacceptability of werden in 10 depends on its status as the helper in the periphrastic future. When werden occurs as the auxiliary for the passive, it may be used in a full range of environments.

8 The projection of features of a given node $A$ onto the head node dominated by $A$ can be viewed as a reflection of head-complement structure. Endocentric constructions typically have one 
member, the head, belonging to the same category as the complex phrase as a whole. Feature grammars of the type employed here use subcategorization in the expansion rules in order to produce just the proper set of phrase markers and avoid needless transformational and/or lexical filtering. Their liability rests, of course, in the proliferation of categories (as subcategories). Gazdar, Pullum and Sag (1980) have developed an analysis of the English verb complex in terms of 'feature grammar' that eliminates the need for AFFIX-HOPPING. This proposal incorporates both feature percolation and the cross classification of the VP with subcategorization. We adapt here their analysis for the German situation.

(i) a. S $\rightarrow$ Comp S

b. $S \rightarrow\{N P\} \vee P$

Syntactic features on VP, $\nabla, V=\{+$ Pres, +Past, +Fut, +INF, +PART, +PASS, +Modal, +Perfect, $+A U X,+z u-I N F\}$

C.

\begin{tabular}{|c|c|c|c|}
\hline $\mathrm{VP} \rightarrow \mathrm{VP} \quad \bar{v}$ & $\alpha$ & $\beta$ & $V$ 's under $\bar{V}$ \\
\hline$[+A U X]$ & +Modal & $+\mathrm{INF}$ & $\begin{array}{l}\text { könn-, müss- } \\
\text { dürf-, , soll-, } \\
\text { woll-, mög- }\end{array}$ \\
\hline & +Perfect & +PART & hab-, sei- \\
\hline & +Fut & + INF & werd- \\
\hline & $\begin{array}{l}\text { This feat } \\
\text { in the ver }\end{array}$ & $\begin{array}{l}\text { able lists } \\
\text { omplex. }\end{array}$ & e subcategoriz \\
\hline
\end{tabular}

d.

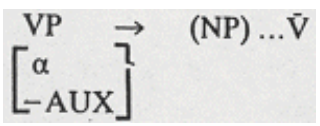

e.

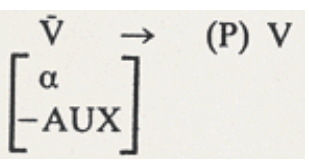

An example of the kind of structures produced by I would be:

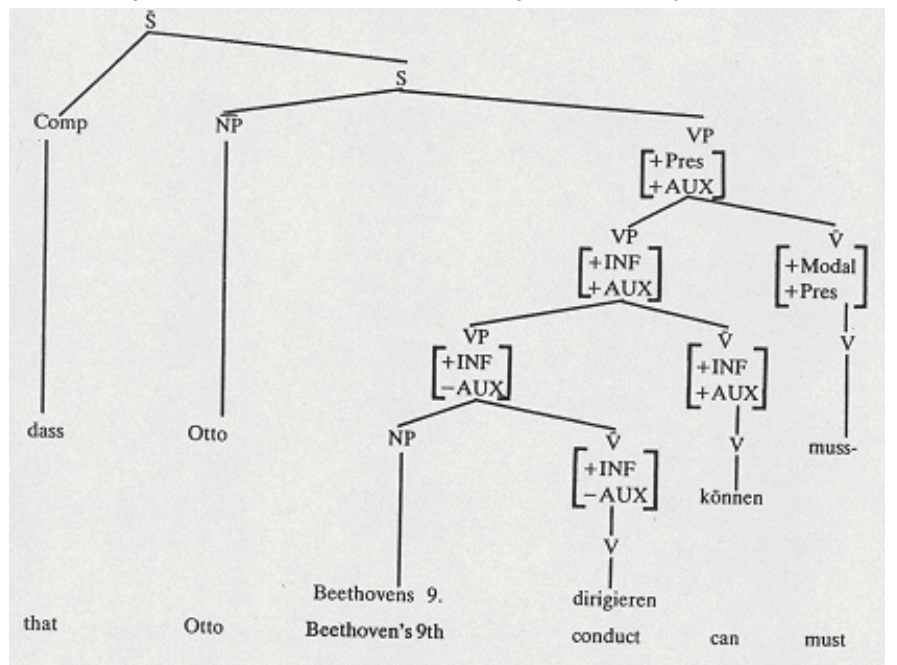

9 The structures in 16 are not unacceptable in every kind of German. The order 16a represents the usual FORM and ORDER in Middle Bavarian according to Willi Mayerthaler (p.c.), which has no inversion rule at all. Infinitivization in this form of German is also found only for modal verbs, brauchen and lassen, but not for the sensory verbs.

10 Paul (1968/1920) and Grimm (1969:1898) list no cases of the perfect infinitive without dependent verbs before Lessing (18th century), while the infinitive with dependent verb is attested in the 13 th century.

11 This sort of rule resembles Labov's variable rules in many respects. In Labov $(1969: 737,738)$ 'a specific quantity $\varphi$ (is associated with every rule) which denotes the proportion of cases in 
which the rule applies to a total population of utterances in which the rule can possible apply.' $\varphi$ is equal to 1 for categorial rules, of course; here, for example, modal.

Our approach employs greater-than signs, which probably reflect values on some markedness scale rather than frequency of occurrence.

12 The respective derivation of the complex haben verfolgen zu können vs. verfolgen gekonnt zu haben occur as follows.

(i)

underlying

AUX AFFIXATION (3 times)

INFNITMZATIONMNERSION

underlying

INFITIMZATIONMMERSION

AUX-AFFIXATION verfolg- INF+könn$P A R T+h a b-z U-+I N F$

verfolg+INF könn+PART zu hab+INF

(zu blocks INFINITIVIZATION from applying)

(ii)

verfolg- INF+könnPART+hab- zu+INF

INF+hab-verfolgINF+könn- zu+INF

INF+hab- verfolg+INF zu könn+INF

13 The derivations of entfernt haben lassen vs. haben entfernen lassen by reordering comes about as follows:

(i)

underlying

AUX-AFFIXATION

INFINITIVIZATION

INVERSION

(ii) entfern- INF+lass PART+hab INF+soll

INVERSION

AUX-AFFIXATION

entfern- PART+hab INF+lass INF+soll entfern- INF+lass PART+hab INF+soll

entfern+INF lass+PART hab+INF soll

entfern+INF +lass+INF hab+INF soll

hab+INF entfern+INF lass+INF soll entfern+PART hab+INF lass+ INF soll 
14 Example 31 is adapted from Grimm (1969/1898). Sanders (1898:122) gives this further example with a participle from Gotthelf.

(i) Heiraten hätte er nicht gebraucht.

Marry would have he not needed [+PART] as well as brauchen. [+INF]

15 In fact, there are only two: schijnen 'appear', which allows neither the DIC nor the participle (also true of lijken 'seem'), and beginnen 'begin', which can surface as a participle or infinitive with variation among speakers.

16 Not only do these 'aspectual' auxiliaries gaan, komen, zitten and staan and as well zijn pattern like the more accepted or traditional auxiliaries, i.e. modals, causatives and sensory verbs, with respect to FORM (they demand the infinitive and not the participle), they also put constraints on the FORM and structure of their complements. A dependent infinitive such as praten in 52b must lose its complementizer prefix te whenever staan is an infinitive. Furthermore, in this connection we observe that zijn behaves in an unexpected fashion here as well. Zijn has two infinitives: zijn and wezen. However, in 52c only wezen and not the usual infinitive FORM of 'be' zijn is required. This form may well be the last visible remnant of a Middle Dutch past participle gewezen, which today always takes the shape geweest. It is unclear to us whether such evidence evidence supports the homophony account of the origin of the DIC proposed by Grimm and Lachmann or not, cf. footnote 1.

17 There are some aspects of inversion not covered in these tables that represent an interpretation. As depicted here German finite haben must obligatorily invert. However, the correct form is usually gelacht hat 'laughed has' and not hat gelacht. This indicates that other factors influence invertability in German. Furthermore, it is difficult to indicate for Dutch that optional inversion with zullen and the other modals depends on the presence of only one INF.

18 The German examples in 72 with the Dutch word order *auf wollte stehen/aus liess sprechen are, of course, also unacceptable for reasons not having to do with particle splitting.

19 Cf. the discussion in Koelmans (1965).

20 Zurich German chooses to disregard the presence of a complementizer in applying 85. Unlike Standard German, one finds sentences such as:

(i) Er fing das Buch an zu lesen.

he began the book Part to read

Both the particle an and the complementizer zu can separate the verb lesen and its immediate direct object das Buch. From Lötscher's data (1978) one must conclude that there is third (probably very limited) way languages may vary their respective rules of Verb Raising. Most allow only V's to be affected by this rule, whereas Zurich German tolerates either V or V'.

21 The inversion/VR facts of Afrikaans closely resemble those of Dutch with some idiosyncrasies, part of which can also be found in Dutch dialects and part of which are peculiar to Afrikaans, (a) Past Participles never invert with the governing auxiliary (similarly for Belgian Dutch).

(i) dat hulle (vir) Piet raakgeloop het/*het raakgeloop.

that they (for: Obj. Marker) Piet met have

(ii) dat die Kind deur sy eie pa geslaan is/*is geslaan.

that the child by his own dad beaten has been

(b) Past Participles are incorporated in the Verbal Complex if the governing auxiliary is het 'have', whereas they are not when governed by a passive auxiliary (this resembles the option of incorporating any past participle in the verbal complex in Belgian Dutch):

(iii) dat hulle (vir) Piet kan/kon raakgeloop het

that they for Piet can/could met have

(iv) dat hy ontslaan kan word/*kan ontslaan word.

that he fired can be

(Note the optional application of Preterite Assimilation, a rule peculiar to Afrikaans.) (c) If het governs two infinitives it must follow that cluster, and if the first infinitive it governs is a modal auxiliary Preterite Assimilation is obligatory:

(v) --, dat ek haar hoor sing het

-- , that I her hear sing have

(vi) --, dat hy niet kon ${ }^{*}$ kan kom het nie

--, that he not could $/{ }^{*}$ can come have not

This exceptional ordering of the perfect auxiliary and two infinitives can also be found in some Belgian dialects of Dutch (cf. Pauwels 1965) and in Zurich German (cf. Lötscher 1978). Other aspects of VR in Afrikaans we leave out of consideration and we refer the reader to Ponelis (1979).

* We would like to thank Erik Reuland for the Frisian data he collected and furnished us. 